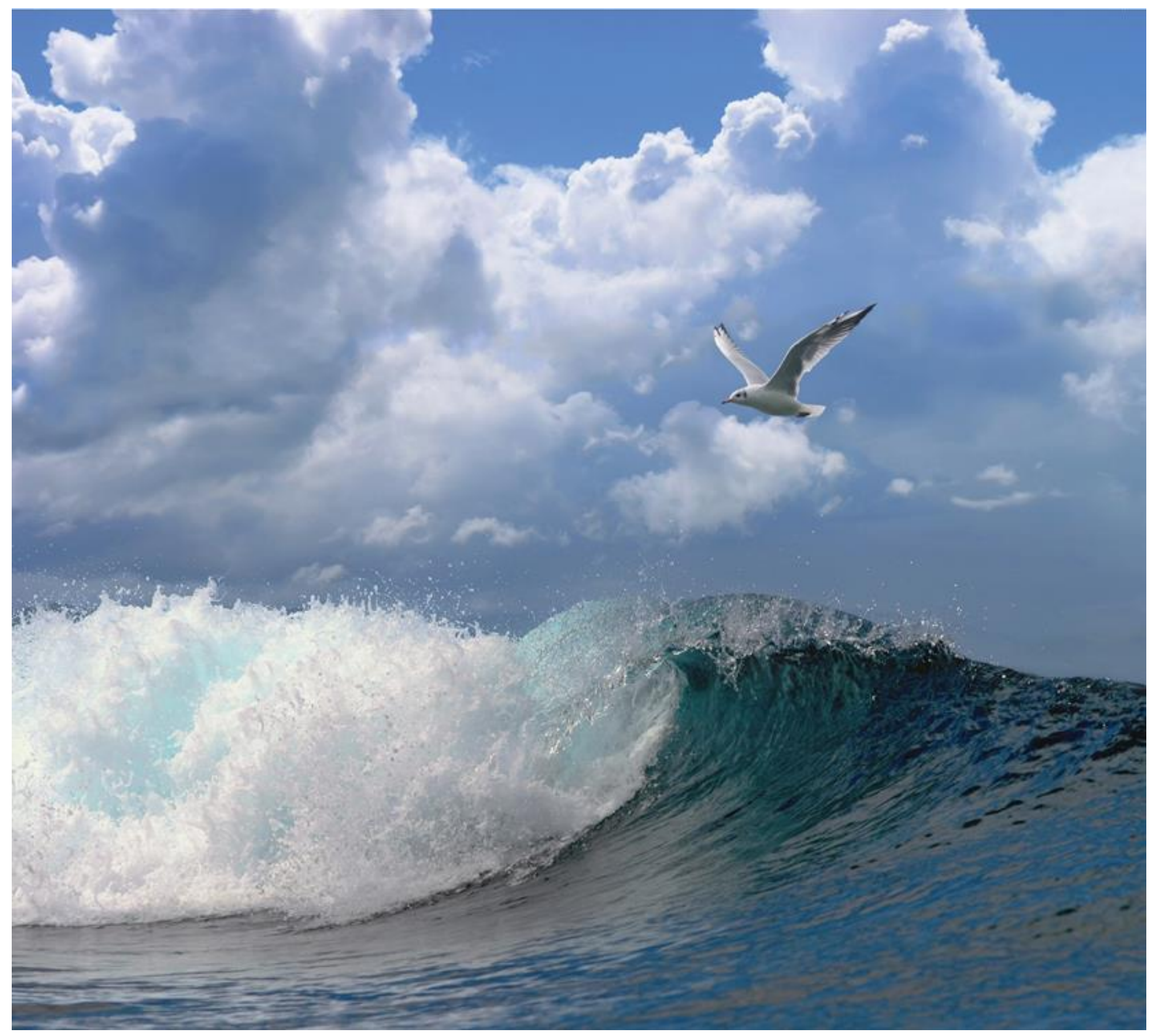

Effecten van visvriendelijke maatregelen op de glasaalindex bij Den Oever 


\section{Effecten van visvriendelijke maatregelen op de glasaalindex bij Den Oever}

Auteurs:

D.M.E. Slijkerman, E.M. Foekema, P. de Vries

Publicatie datum: december 2017 
Slijkerman D.M.E., E.M. Foekema, P. de Vries 2017.. Effecten van visvriendelijke maatregelen op de glasaalindex bij Den Oever. Wageningen, Wageningen Marine Research (University \& Research centre), Wageningen Marine Research report C109/17. 48 pp.

Keywords: Glasaal index, Den Oever, vismigratie, spuibeheer

Dit project is gefinancierd door DUPAN en ministerie van EZK. De BAScodes horend bij dit onderzoek zijn: BO-20-010-127

Opdrachtgevers: Stichting DUPAN

t.a.v. dhr A. Koelewijn

Postbus 249

6700 AE Wageningen
Ministerie van Economische Zaken en Klimaat

t.a.v. mw M. Snijdelaar

Postbus 20401

2500 EK Den Haag

Dit rapport is gratis te downloaden van https://doi.org/10.18174/429680

Wageningen Marine Research verstrekt geen gedrukte exemplaren van rapporten.

Wageningen Marine Research is ISO 9001:2008 certified.

\section{(c) 2017 Wageningen Marine Research Wageningen UR}

Wageningen Marine Research institute of Stichting Wageningen Research is registered in the Dutch traderecord nr. 09098104, BTW nr. NL 806511618
The Management of Wageningen Marine Research is not responsible for resulting damage, as well as for damage resulting from the application of results or research obtained by Wageningen Marine Research, its clients or any claims related to the application of information found within its research. This report has been made on the request of the client and is wholly the client's property. This report may not be reproduced and/or published partially or in its entirety without the express written consent of the client. 


\section{Inhoudsopgave}

\section{I nhoudsopgave}

$1 \quad$ Samenvatting

2.1 Glasaal en de glasaalindex

2.2 Afsluitdijk, glasaalintrek en visvriendelijke maatregelen

2.2.1 Nul-situatie

2.2.2 Visvriendelijke maatregelen

2.3 Doel van de studie 12

$\begin{array}{lll}2.3 .1 & \text { Onderzoeksvragen en hypotheses spuikom } & 12\end{array}$

$\begin{array}{ll}\text { 2.3.2 Onderzoeksvragen en hypotheses Schutkom } & 12\end{array}$

$3 \quad$ Materiaal en methoden $\quad 13$

3.1 Generieke aanpak 13

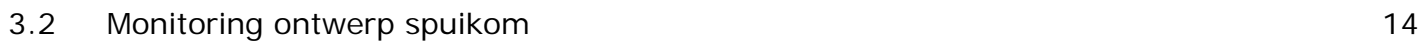

$\begin{array}{ll}3.3 & \text { Monitoring ontwerp schutkom } \\ \end{array}$

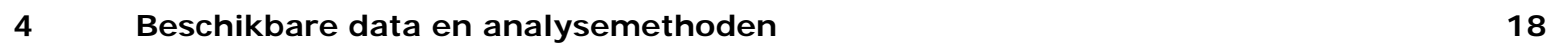

$\begin{array}{lll}4.1 & \text { Spuikom } & 18\end{array}$

$\begin{array}{ll}4.2 & \text { Schutkom } \\ 4.3 & 21\end{array}$

$\begin{array}{lll}4.3 & \text { Databewerking } & 22\end{array}$

4.3.1 Koppeling vangstwaarnemingen aan spuiregime $\quad 22$

4.3.2 Bepalen gevangen fracties in de ruimte (spui- en schutkom) 22

4.3.3 Correlatie vangsten index monitoring en merk-terugvang-experiment 23

$\begin{array}{lll}4.3 .4 & \text { Statistiek } & 23\end{array}$

5 Resultaten $\quad 24$

$\begin{array}{lll}5.1 & \text { Spuikom } & 24\end{array}$

5.1.1 Glasaalvangsten in indexmonitoring $\quad 24$

$\begin{array}{lll}5.1 .2 & \text { Kruisnet bemonstering } & 25\end{array}$

5.1.3 Invloed van spuibeheer op glasaalverdeling 26

$\begin{array}{lll}5.1 .4 & \text { Invloed van spuibeheer op de verblijftijd van glasaal } & 27\end{array}$

5.1.5 De relatie tussen de aantallen aanwezige glasalen en de glasaalindex 28

$\begin{array}{lll}5.2 & \text { Schutkom } & 30\end{array}$

5.2.1 Effecten van vismaatregelen op de verdeling van glasaal 30

5.2.2 Effecten van visintrekmaatregelen op de verblijftijd van glasaal 32

5.2.3 Vishevelmonitoring 33

5.3 Glasaal beweging tussen de kommen 34

5.3.1 Van Spuikom naar Schutkom $\quad 34$

5.3.2 Van schutkom naar spuikom 34

$\begin{array}{lll}5.4 & \text { Bestandsschattingen } & 35\end{array}$

$\begin{array}{llr}6 & \mathbf{3 7}\end{array}$

$\begin{array}{lll}6.1 & \text { Opzet onderzoek en beschikbare informatie } & 37\end{array}$

$\begin{array}{lll}6.1 .1 & \text { Onderzoeksmethoden } & 37\end{array}$

6.1.2 Co-variabelen in de glasaalvangst 38

6.1.3 Merk en terugvangst experimenten 38

6.1.4 Informatie over spui en visintrekstanden 39

$\begin{array}{llr}7 & \text { Conclusies } & \mathbf{4 0}\end{array}$ 
7.1 Samenvattend

7.2 Effecten van de glasaalmaatregel op glasaal in de spuikom

40

7.3 Effecten van maatregelen op glasaal in de Schutkom

41

7.4 Invloed van de maatregelen op de glasaal index

8 Dankwoord

43

$9 \quad$ Kwaliteit

43

10 Referenties

44

11 Verantwoording

45 


\section{$1 \quad$ Samenvatting}

In 2016 zijn nabij het spuisluis en schutsluiscomplex bij Den Oever visvriendelijke migratiemaatregelen geïmplementeerd. De maatregelen hebben als doel de glasaal en andere vis sneller en makkelijker te laten migreren tussen het zoute en het zoete water. De recente maatregelen betreffen nabij de schutsluizen de inwerkingstelling van een vishevelpassage en het uitvoeren van extra loze schuttingen. In de Stevinsluizen zijn twee verschillende visvriendelijke maatregelen van toepassing. Het "visspuien" wordt sinds 1992 uitgevoerd en betreft het spuien van zoet water op de Waddenzee. Hierbij heeft vis de gelegenheid heeft zowel van zoet naar zout als van zout naar zoet te migreren. Omdat de stroomsnelheid hoog is, wordt verondersteld dat kleinere vis zoals glasaal niet goed kan migreren naar het zoete binnenwater. De zgn. glasaalmaatregel is sinds 2016 ingesteld, en betreft visvriendelijke spui waarbij elke kentering kortstondig zout water wordt gespuid naar het zoete water, omwille van de glasaalintrek.

Bij Den Oever vindt ook de langslopende monitoring van glasaal in Nederland plaats. Deze monitoring wordt gebruikt voor de voor de zgn. glasaalindex: een indicator voor het verloop van het glasaalbestand.

De recent genomen maatregelen kunnen tot gevolg hebben dat Europa's langstlopende glasaalmonitoring een trendbreuk heeft. Een eventuele trendbreuk zorgt ervoor dat een vergelijking met indexcijfers van voorgaande jaren niet langer goed mogelijk is.

Indien een trendbreuk aannemelijk is zal een correctiefactor noodzakelijk zijn om een continue reeks van de glasaalindex te kunnen behouden. Het in dit rapport beschreven onderzoek had als doel vast te stellen óf de recent ingestelde visvriendelijke maatregelen bij Den Oever een effect hebben op de glasaalindex en als dit het geval is te onderzoeken hoe de ontstane trendbreuk gecorrigeerd kan worden.

Het meerjarig onderzoek bij de Stevinsluizen, in de spuikom, was gerelateerd aan de glasaalmaatregel. Het had als doel inzicht te krijgen in veranderingen de verdeling en verblijftijd van glasaal. Het onderzoek bestond uit kruisnetmonitoring, merk-en terugvangstexperimenten en analyses van de vangsten uit de indexmonitoring.

Het meerjarig onderzoek in de schutkom had specifiek betrekking op de vishevelpassage en extra loze schuttingen van de schutsluis die daar in 2016 in werking traden. Ook dit onderzoek had als doel inzicht te krijgen in veranderingen de verdeling en verblijftijd van glasaal. Het onderzoek bestond uit kruisnetmonitoring, merk-en terugvangst- experimenten.

In het rapport staat uitgebreid beschreven in welk jaar, waar en wanneer welke deelonderzoeken hebben plaatsgevonden. Het onderzoek in 2015 hebben we gebruikt als uitgangssituatie (T0), zónder de visvriendelijke migratiemaatregelen. De opvolgende jaren werden gebruikt om de invloeden van de maatregelen te onderzoeken.

\section{Effecten van de glasaalmaatregel in de Stevinsluizen}

De vangsten in de spuikom die gedaan zijn tijdens de verschillende merk-en terugvangexperimenten, kruisnetmonitoring, en indexmonitoring zijn gerelateerd aan de instellingen van het spuicomplex (Stevinsluizen). De instellingen betreffen het wel/niet spuien, wel/niet visspuien, wel/niet glasaalmaatregel in werking.

In de Stevinsluizen kunnen geen eenduidige effecten worden aangetoond van de maatregelen op glasaal. Dit heeft vooral te maken met de kwaliteit en de datadichtheid van de gegevens. In de praktijk bleek achteraf dat de instellingen niet altijd goed werden gecommuniceerd en of gedocumenteerd. Dit heeft grote impact op de analyse en de kracht van de conclusies teweeggebracht. Voor een groot deel van de onderzoeksgegevens is het onduidelijk gebleven welke spui/visintrek instelling er in werking was.

Op basis van de resultaten van de uitgevoerde experimenten kan geen uitspraak worden gedaan over de (veranderde) verblijftijd van glasalen in de spuikom en of de maatregelen daarop van invloed zijn. 
Een analyse van de gegevens waarbij het spuibeheer wél duidelijk is, indiceert dat er relatief minder glasaal ophoopt vlak voor de sluisdeur als de glasaalmaatregel in werking is. Echter de relatie tussen glasaalmaatregelen en de verdeling van glasaal is niet eenduidig waardoor het effect niet verder kon worden gekwantificeerd.

\section{Effecten van visvriendelijke maatregelen in de schutkom}

De analyses van de vangsten in de schutkom richtten zich op de verdeling/ophoping van glasaal locaties vlak voor de sluisdeuren, en de verblijftijd in de schutkom.

Op basis van het onderzoek zijn geen aanwijzingen gevonden dat de verblijftijd van glasaal veranderde toen in 2016 de glasaal-maatregelen actief werden.

Het aandeel glasaal dat zich nabij de schutsluis en de nabijgelegen RWZI uitlaat ophoudt is echter lager in 2016 mét de maatregelen in werking vergeleken met een jaar eerder (zonder maatregelen). Dit indiceert dat de maatregelen waarschijnlijk een effect hebben op de ophoping en verdeling van glasaal op deze posities.

\section{Effecten van visvriendelijk spuibeheer op de indexwaarde}

De vraag bij dit onderzoek was, of de aanwijzingen voor effecten op de glasaalindex-waarde hard genoeg gemaakt konden worden. Zo niet, dan zijn er twee mogelijke verklaringen. Of de effecten van de maatregelen zijn er niet, óf het onderzoek laat dit niet zien. Als effecten worden aangetoond, dan is het vervolgens aan de orde om te bepalen of de mate van de effecten ook te kwantificeren zijn. Als de effecten niet zijn aan te tonen, zijn ze ook te niet kwantificeren, en kan de eventuele correctie op de index ook niet worden bepaald.

In dit onderzoek zijn geen harde aanwijzingen dat de maatregelen effect hebben op de glasaalverblijftijd en verdeling in het gebied, daarmee kunnen de effecten ook niet kwantificeren en dus ook geen correctie uitvoeren. De onderzoeksresultaten bevatten te veel onzekerheden om duidelijke uitspraak te kunnen doen in welke mate de glasaalindex zal worden beïnvloed door de maatregelen. Het gegeven dat er slechts een subtiele verandering van de verdeling van glasalen lijkt te ontstaan wanneer de glasaalmaatregel wordt toegepast suggereert echter geen enorme verschillen in de verblijftijden van glasaal. De invloed op de glasaalindex zal hiermee waarschijnlijk beperkt zijn. Op basis van dit onderzoek kunnen we dus niet uitsluiten noch hard maken dat er effecten van de maatregelen op de glasaalindex-vangsten, en dus de indexwaarde, zal zijn. Een correctiefactor is dan ook niet vastgesteld.

Om de voorzichtige bevindingen in dit onderzoek nader te onderzoeken kan een aanvulling op het onderzoek worden gedaan. Hierbij stellen wij een data-analyse van de indexdata over een meerjarige periode voor, en deze te koppelen aan de klepstanden en debiet gegevens van het sluiscomplex. De beschikbaarheid van deze data kwam pas in een laat stadium naar voren en kon niet worden toegepast in dit onderzoek. Om over te gaan op een dergelijke exercitie is het eerst nodig om met de betrokken instanties verder te bespreken wat deze informatie exact kan betekenen i.r.t. spui, vis-spui en glasaalintrek, en hoe de vertaling te maken is naar de eventuele aanvullende data-analyse. Daarna kan bepaald worden of een dergelijke analyse van toegevoegde waarde is op onderliggende analyse. Om meer inzicht te krijgen in een eventuele trendbreuk en effecten van spuistanden/visintrek stellen wij voor dat in aanvulling op de indexmonitoring, onderzoek wordt uitgevoerd waarbij de ontwikkeling van het aanbod van glasaal gevolgd wordt door periodiek, bijvoorbeeld eens per 5 jaar, het aanbod in de spuikom te schatten op basis van kruisnetmonitoring. 


\section{$2 \quad$ Introductie}

\subsection{Glasaal en de glasaalindex}

De aal (Anguilla anguilla (L.)) is een uitzonderlijke vis. De voortplanting vindt ver van Europa, op de Atlantische Oceaan plaats, op een nog steeds onbekende locatie- nabij de sarrogasso zee (Schmidt 1922, Tesch 2003). Nabij het Europese continent vormt de aallarve zich om in een jonge, doorzichtige aal: de glasaal, en heeft dan een lengte van ongeveer $7 \mathrm{~cm}$. Op de golfstroom voert de larve over de oceaan richting de Europese kust. De glasaal verspreidt zich over Europa, en na intrek groeien ze op in de binnenwateren.

Aal groeit in Nederland relatief langzaam, waarschijnlijk vanwege de lage watertemperatuur (Wolfshaar et al., 2015). Bij een lengte van 35 tot $45 \mathrm{~cm}$ (mannetjes) resp. boven de $45 \mathrm{~cm}$ (vrouwtjes) verandert de aal van uiterlijk (aangeduid als schieraal, vanwege de witte=schiere buik) en trekt weer terug naar zee, om zich eenmalig voort te planten en daarna te sterven.

Aal is een wijdverbreide vissoort in Nederland en is verreweg de belangrijkste doelsoort van de visserij in de binnenwateren. De ecologische betekenis van de aal als voedsel voor diverse vogelsoorten is aanzienlijk (Dekker 2004).

leder voorjaar trekken de jonge alen, glasaal, vanuit zee onze binnenwateren in. Nabij Den oever- op het Stevinsluizencomplex- wordt aan de Waddenzee-zijde sinds 1938 de aanwezigheid van glasaal gemonitord met behulp van een kruisnet. De monitoring berust op twee aannames (Dekker en Van Willigen, 1997)

- De kruisnetvangsten zijn indicatief voor de hoeveelheid aanwezige glasaal

- $\quad$ De hoeveelheid aanwezige glasaal is indicatief voor de intrek

Op basis van de jaarlijkse vangsten wordt de zgn. glasaalindex bepaald. De data reeks en de index laat zien dat sinds de jaren tachtig de hoeveelheid gevangen glasaal terugloopt. Niet alleen in Nederland, maar in heel Europa (ICES, 2017).

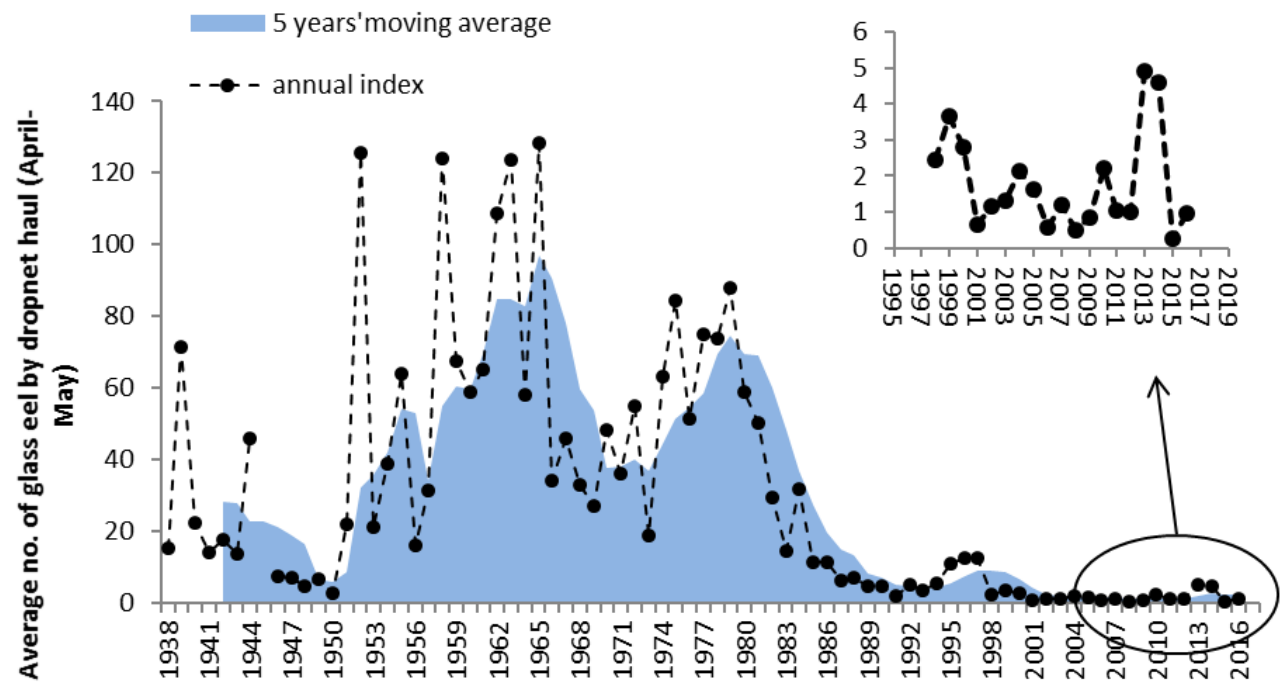

Figuur 1 Trend indices (gemiddeld aantal glasaal per trek in april en mei) bij Den Oever (19382016) (ICES, 2017) 


\section{Glasaal index: een indicatie voor jaarklassterkte}

\section{Op basis van: Van der Sluis et al., (2016):}

Op 13 plaatsen, verspreid langs de Nederlandse kust, wordt de intrek van glasaal bemonsterd van begin maart tot half juni. De bemonstering gebeurt met een kruisnet (ook wel totebel genoemd). Het net bestaat uit een vierkant metalen frame van $1 * 1 \mathrm{~m}$, waarin een ietwat conisch net is bevestigd, met een maaswijdte van $1^{*} 1 \mathrm{~mm}$. Het frame is bevestigd aan vier lijnen, die na een knoop, gezamenlijk naar boven lopen. In het midden van het net is een gewicht bevestigd. Het net wordt aan het touw naar beneden gelaten voor de sluis, totdat de bodem bereikt is. Na ongeveer 5 minuten wordt het net handmatig opgehaald, met een snelheid van 1 meter per seconde. Het aantal gevangen glasalen wordt geteld.

In het verleden werden dikwijls zeer grote aantallen glasalen gevangen; in deze gevallen werd het volume van de glasalen gemeten (door verdringing van water in een emmer) en werd daaruit het aantal geschat middels een conversie-factor (Dekker 2004).

De monitoring van glasaal vindt plaats door een bemonstering van de concentratie glasaal direct voor de diverse sluizen, op de overgang tussen binnenwater en zee (Figuur 7). De langstlopende monitoring vindt, sinds 1938, plaats in Den Oever.

In Den Oever wordt deze bemonstering elk uur uitgevoerd, van 22.00 tot 5.00 uur. Op andere plaatsen (bv Stellendam, Katwijk) vinden de bemonstering plaats tijdens de wisseling van de wacht van de sluismeesters, meestal om 23.00 uur. Elders worden twee trekken gedaan op een voor de vrijwilliger geschikt moment, meestal in de voornacht.

De index bij Den Oever wordt uitgedrukt als de aantallen glasaal per kruisnettrek voor de maanden april en mei.

\subsection{Afsluitdijk, glasaalintrek en visvriendelijke maatregelen}

\subsubsection{Nul-situatie}

Op de Afsluitdijk bevinden zich 2 spuisluiscomplexen. Het complex bij Den Oever (Stevinsluizen) is het grootste met 3 groepen met ieder 5 spuikokers ( 15 kokers). Ook is er bij Den Oever een schutsluis aanwezig (Figuur 2). Het onderzoek in dit rapport concentreert zich op de Stevinsluizen en de Schutsluis.

Dekker (2004) beschrijft de visintrek omstandigheden zonder visvriendelijke maatregelen nabij de Afsluitdijk als volgt:

Hier doet zich een onnatuurlijke situatie voor: een scherpe overgang van zout naar zoet water, op een plaats waar wel een verticale getijdencyclus (hoogte) aanwezig is, maar tot nog toe geen water naar binnen kon stromen (geen stroming gerelateerd aan de getijdencyclus). Als gevolg daarvan kan het selectief getijden transport de glasaal tot aan de sluisdeur brengen, maar niet verder. Vlak voor de sluisdeur ontstaat hierdoor een ophoping van vis (Dekker en van Willigen 2000), die wacht op een gelegenheid om met de vloedstroom door de sluizen naar binnen te stromen. Elke dag weer ondervinden de glasalen voor de sluis de vloedstroom. Het is dan ook niet verwonderlijk, dat in deze situatie vrijwel geen sprake is van actief zwemgedrag: een geboden gelegenheid om tegen een zoetwaterstroom in te zwemmen (d.w.z. de plaatsing van een conventionele glasaal/pootaal-val, volgens het principe van Heermans en van Willigen, 1974) blijkt maar zeer weinig benut te worden. De glasaal wacht kennelijk liever op een gelegenheid om toch met de vloed mee te zwemmen, en hoopt zich op voor de sluis.

Toch komt de glasaal wel degelijk door de sluizen het IJ sselmeer in. Het lijkt het meest waarschijnlijk, dat er bij tijd en wijle wel degelijk een hoeveelheid water uit de Waddenzee door de sluizen naar binnen stroomt. Dit zou waarschijnlijk met name optreden aan het eind van een spuiperiode, wanneer de vloed, met daarin de zwemmende glasaal, weer opkomt, en de sluizen net niet op tijd gesloten worden. De glasaal voor de sluizen wacht in feite op deze zeldzame gelegenheden, om naar binnen te komen (Dekker en van Willigen 2000). Dit verklaart waarschijnlijk ook, waarom gemerkte glasaal voor de sluizen, ondanks dagelijkse spui van water naar de Waddenzee, wekenlang voor de sluis aanwezig bleef (Dekker en van Willigen 1997). 


\subsubsection{Visvriendelijke maatregelen}

Om de situatie als hierboven beschreven te verbeteren zijn er diverse visvriendelijke maatregelen ontworpen, gepland en inmiddels al deels uitgevoerd. Figuur 2 geeft een overzicht van het sluizencomplex en de locatie waar visvriendelijke maatregelen zijn ingevoerd.

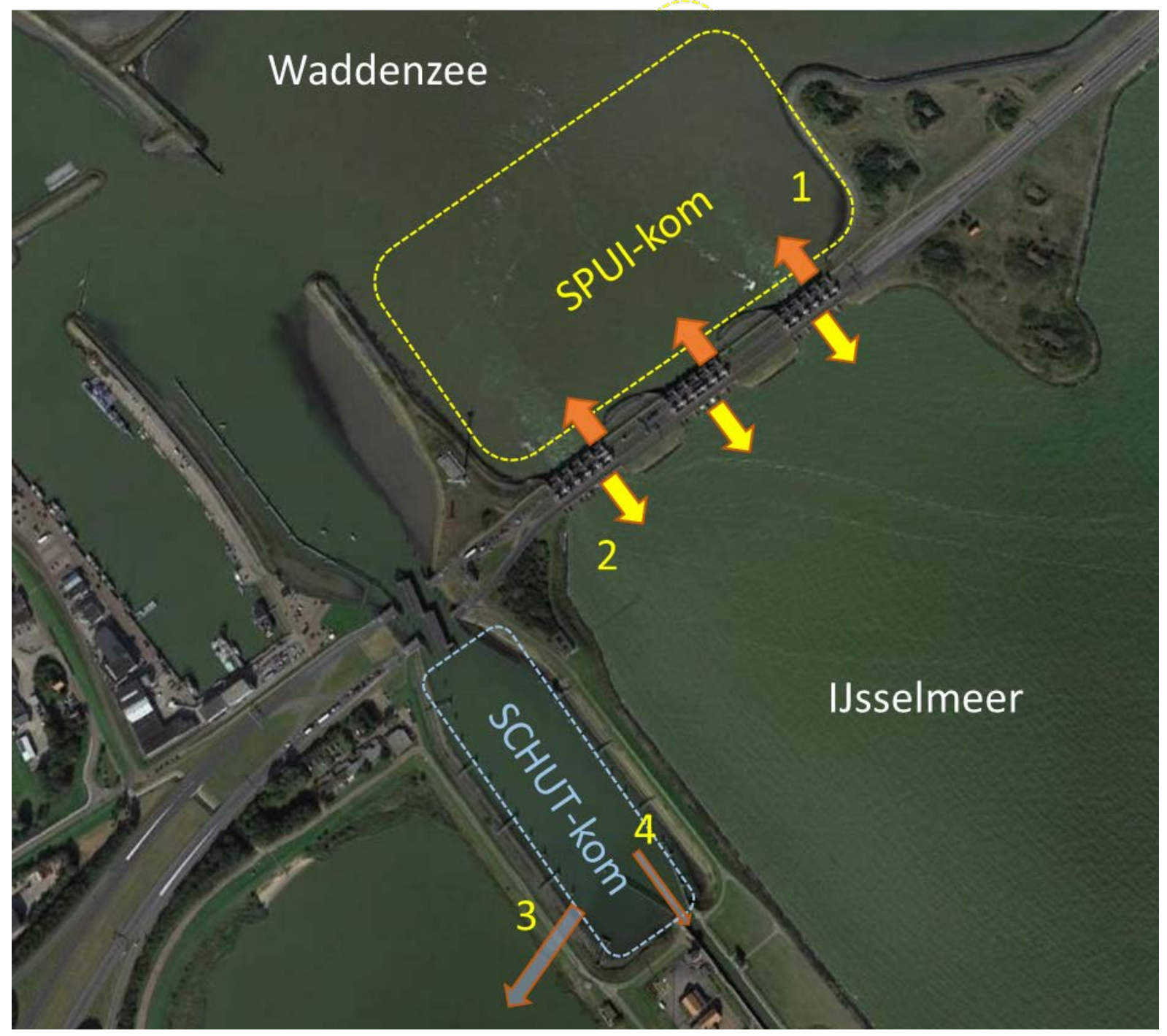

Figuur 2 Situatie schets Stevinsluizen complex bij Den Oever en de diverse visvriendelijke maatregelen. 1: visvriendelijk spuien zoet naar zout, 2: visvriendelijk spuien zout naar zoet, 3: vispassage, 4: visvriendelijk schutten.

De maatregelen die betrekking hebben op het complex bij Den Oever zijn de volgende:

\section{Visvriendelijk spuibeheer: Spuien van zoet water met visintrek “Visspuien”}

Via de spuisluizen wordt overtollig water vanuit het achterland afgevoerd richting zee. De spuisluizen worden geopend wanneer het zoetwaterniveau hoger is dan het zoutwaterniveau. Er wordt alleen gespuid tijdens opkomend en afgaand water met een lager peil aan de buitenzijde dan aan de binnenzijde, dus maximaal 2 maal per etmaal en bij voldoende aanbod van zoetwater.

De stroomsnelheid van de spuistroom is zo hoog dat vis vanuit de Waddenzee hier niet of nauwelijks tegenin kan zwemmen om het IJ sselmeer te bereiken (Winter et al., 2014). Van enkele soorten is de intrek efficiëntie bepaald zoals zeeforel, zeeprik en houting (De Vaate et al., 2003). Wat de intrek van kleinere soorten is zoals driedoornige stekelbaars, botlarven en (dus) ook glasaal, is onbekend (Griffioen et al. 2014).

Om migratie mogelijkheden van (grotere) vis tijdens het spuien van zoetwater uit het IJ sselmeer te vergroten wordt sinds 1992 visvriendelijk spuibeheer toegepast. 
Bij het visvriendelijk spuien ("visspuien") met visintrek staan alle schuiven van de spuikokers volledig open met uitzondering van de 2 buitenste kokers van elke groep van 5 . Het visspuien gebeurd wanneer dit volgens de protocollen van RWS wordt toegelaten en dus ook in die gevallen wanneer de middelste deuren per koker dicht zijn. Bij het visspuien wordt van de schuiven alleen de onderste helft geopend $(50 \mathrm{~cm}$ ), waardoor er een kier ontstaat. Dit zijn dus maximaal zes van de 15 spuikokers bij de Stevinsluizen. Hierdoor is de gemiddelde stroomsnelheid in deze kokers lager t.o.v. de andere kokers mits deze volledig openstaan en kunnen (grote) vissen tegen de stroom in naar het IJ sselmeer zwemmen, waarbij ze alleen onder de schuiven door een korte sprint moeten doen. De vis-spuikokers worden geopend wanneer het waterniveau in de Waddenzee $20 \mathrm{~cm}$ lager staat dan in het IJ sselmeer, dat is ongeveer 15 minuten eerder dan de overige kokers. De deuren van de kokers gaan dicht bij gelijke waterstanden.

Bij hoog wateraanbod- en dus hoog spui aanbod- wordt geen vismigratiebeheer toegepast om alle spuikokers maximaal te benutten omwille van de waterbalans.

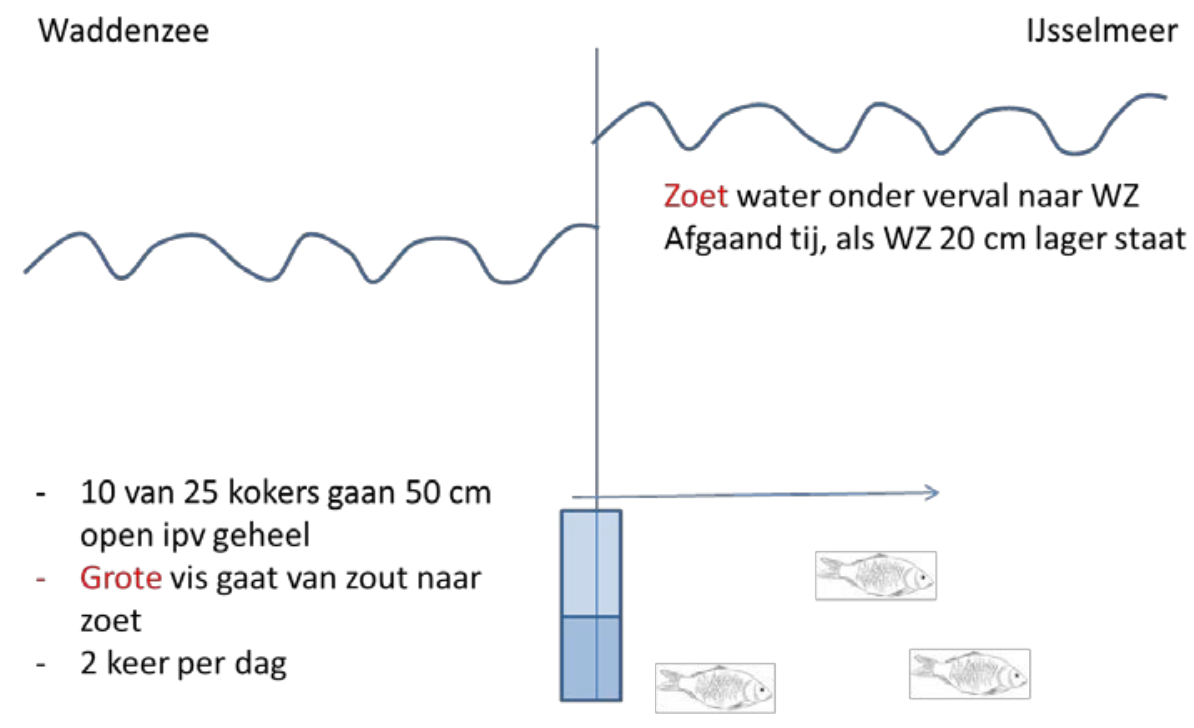

Figuur 3 Visuele schets visvriendelijk spuibeheer ("visspui"): Spuien van zoet water met visintrek. In werkelijkheid heeft elke koker twee schuiven, een noordelijke schuif aan de Waddenzee zijde en een zuidelijke schuif aan de IJsselmeer zijde. Vissen moeten zodoende twee schuiven passeren alvorens zij het IJ sselmeer bereiken.

2. Visvriendelijk spuibeheer: Spuien van zout water met visintrek ("glasaal maatregel") Het doel van deze variant op spuien is om voorafgaand aan het spuien een geringe hoeveelheid zout water uit de Waddenzee naar het IJ sselmeer te laten stromen, en tegelijkertijd een grote hoeveelheid vis mee te laten migreren van zout naar zoet water. Het gaat hierbij in eerste instantie om de intrek van de zogenaamde zwakke zwemmers, zoals glasaal, driedoornige stekelbaars, bot(larven) en spiering. Hoewel de focus op glasaal en andere kleinere vis ligt, zullen de toegenomen mogelijkheden ook betrekking hebben op grotere mogelijkheden voor sterke zwemmers (zalm, zeeforel, houting, fint etc.) om binnen te komen. Deze maatregel wordt sinds eind $2015^{1}$ toegepast op de Afsluitdijk.

De spuikokers worden tweemaal per dag geopend wanneer het waterpeil in de Waddenzee $15 \mathrm{~cm}$ hoger staat dan in het IJ sselmeer en het afgaand tij is. Hierdoor is een zout waterstroom naar het IJ sselmeer onder vrij verval mogelijk. De deuren van de kokers gaan na maximaal 5 minuten weer dicht. Het maximaal toelaatbare volume aan zeewater dat het IJ sselmeer mag instromen (zoutbelasting) is hierbij bepalend voor de openstellingstijd en het peilverschil.

Omdat het zoute water zwaarder is dan het zoete verzameld het zoute water met de meegekomen vis zich in een verdieping in de IJ sselmeerbodem achter de sluizen. Bij een volgende (zoete) spuigang

\footnotetext{
${ }^{1}$ Ten tijde van schrijven is bekend dat deze maatregel sinds 2015 is toegepast. Ten tijde van het onderzoek was er sprake van dat de maatregel pas in de loop van 2016 zou worden ingesteld.
} 
waarbij zoet water van IJsselmeer naar de Waddenzee wordt geloosd, wordt dit zoute water weer teruggevoerd naar de Waddenzee. De aanname is dat eerder gemigreerde vis dan al verder het IJ sselmeer in gezwommen is.

In dit onderzoek en onderliggende rapportage refereren we aan deze maatregel als de zgn.

"glasaalmaatregel".

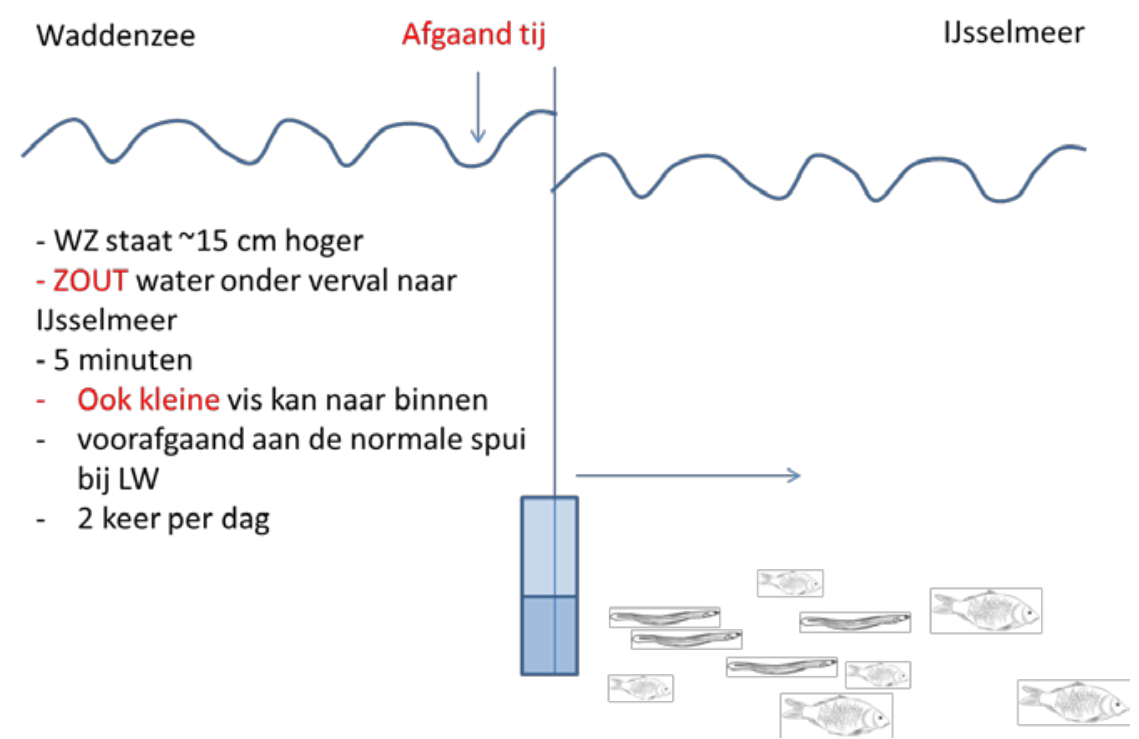

Figuur 4 Visuele schets visvriendelijk spuibeheer "Glasaal maatregel": Spuien van zoet water met visintrek. In werkelijkheid heeft elke koker twee schuiven, een noordelijke schuif aan de Waddenzee zijde en een zuidelijke schuif aan de IJ sselmeer zijde. Vissen moeten zodoende twee schuiven passeren alvorens zij het IJ sselmeer bereiken.

\section{Visvriendelijk schutsluisbeheer}

Een schutsluis heft het waterstandsverschil tussen IJsselmeer en Waddenzee op voor schepen zodat deze naar binnen of buiten kunnen varen. Bij het visvriendelijke schutten wordt er niet alleen geschut voor schepen, maar worden extra 'loze' schuttingen uitgevoerd ten behoeve van de visintrek. Tussen 22 avonds en 6 uur 's ochtends wordt ieder uur geschut wanneer er door de scheepvaart geen beroep op de sluis gedaan wordt. De rinketten in de deuren aan de kant van de Waddenzeegaan eerst open, om het peil te nivelleren gevolgd door de deuren, waarna de rinketten in de deuren aan de IJ sselmeer kant opengaan gevolgd door de deuren. Het visvriendelijk schutten vindt plaats wanneer het peil van de Waddenzee lager is dan $180 \mathrm{~cm}+$ NAP.

Het visvriendelijk schutsluisbeheer geeft, naast de intrek van diadrome vis, ook mogelijkheden aan uitgespoelde zoetwatervis om weer het IJ sselmeer binnen te zwemmen.

Bij Den Oever wordt vanaf 2016 visvriendelijk schutsluisbeheer uitgevoerd. De frequentie waarmee dit in de prakrijk gebeurd is echter onduidelijk. In dit rapport hanteren we ook wel de term "schutten".

\section{Vishevelpassage}

Aan de westkant van de schutsluis bij Den Oever is sinds 2016 een vispassage in werking, die de migratie van vis tussen de Waddenzee en het IJsselmeer dient te bevorderen. Deze vispassage is specifiek bedoeld voor kleinere vissoorten. De passage bestaat uit een buis door de dijk die in verbinding staat met een bak waarin het IJ sselmeerpeil altijd hoger staat dan de Waddenzee. Hierdoor stroomt er altijd zoet water door de buis. De zoete lokstroom trekt vissen aan. De vissen verzamelen zich in een bak door tegen de stroom in te zwemmen. Op gezette tijden wordt de vis in deze bak over de dijk geheveld naar het zoete water door een vacuümpomp. Daarna kan de vis doorzwemmen naar paai- en opgroeigebieden in het IJ sselmeer of het achterland. 


\subsection{Doel van de studie}

De visvriendelijke maatregelen hebben als doel de migratiemogelijkheden voor glasaal om bij Den Oever het IJ sselmeer binnen te trekken te vergroten, maar betekenen mogelijk het einde van de consistentie van de omstandigheden waarbij de Glasaalindex bij Den Oever wordt bepaald.

De aanpassingen bij Den Oever (zoals de hevelpassage en het visvriendelijk spuibeheer) veranderen mogelijk de verblijftijd en verspreiding van glasaal voor de spuisluizen. Harde aanwijzingen zijn hiervoor echter nog niet.

Indien de doortrekbaarheid wordt verhoogd zullen er gemiddeld minder glasalen worden gevangen in de glasaalindex-monitoring, met een lagere index tot gevolg, terwijl er geen daadwerkelijke daling van de aanvoer van glasaal heeft plaatsgevonden. De glasaalindex zal daardoor geen vergelijkbaar beeld opleveren ten opzichte van het verleden.

Het in dit rapport beschreven onderzoek heeft als doel vast te stellen of de recent ingestelde visvriendelijke maatregelen bij Den Oever een effect hebben op de glasaalindex en als dit het geval is om te onderzoeken hoe de ontstane trendbreuk gecorrigeerd kan worden.

\subsubsection{Onderzoeksvragen en hypotheses spuikom}

Het onderzoek werd uitgevoerd in de jaren 2015, 2016 en 2017 in het gebied ten noorden (Waddenzee kant) van de Stevinsluizen en had als doel inzicht te krijgen in:

- De relatie tussen de aantallen in het onderzoeksgebied aanwezige glasalen en de kruisnetvangsten ten bate van de glasaalindex;

- De verspreiding van de glasalen in het onderzoeksgebied;

- $\quad$ De verblijftijd van de glasalen in het onderzoeksgebied;

Om zodoende een vergelijking te kunnen maken tussen de nul-situatie in 2015 en de situatie in 2016 en 2017 met visvriendelijke maatregelen in werking.

De volgende hypotheses werden voor de spuikom opgesteld:

- De glasaalindex vangsten correleren in alle jaren met de dichtheden glasaal vlak voor de sluisdeuren

- Door de glasaalmaatregel vindt er in de jaren 2016 en 2017 minder ophoping van glasaal voor de sluisdeuren plaats dan in 2015.

- Door de glasaalmaatregel is de verblijftijd van glasaal in het onderzoeksgebied korter in 2016 en 2017 dan in 2015

\subsubsection{Onderzoeksvragen en hypotheses Schutkom}

Het onderzoek in de schutkom had specifiek betrekking op de visvriendelijke maatregelen die daar in 2016 in werking zouden treden, de vishevel passage en extra loze schuttingen van de schutsluis. Hoe onderzoeksdoel was vast te stellen of deze maatregelen invloed hebben op:

- De verspreiding van de glasalen in het onderzoeksgebied;

- De verblijftijd van de glasalen in het onderzoeksgebied;

- De uitwisseling van glasalen vanuit de schutkom.

De volgende hypotheses werden voor de schutkom opgesteld:

- Door de maatregelen zal er minder ophoping van glasaal plaatsvinden rond het lozingspunt van de RWZI.

- Door de maatregel is de verblijftijd van (gekleurde) glasalen in het onderzoeksgebied korter in 2016 dan in 2015

- Door glasaalvriendelijk spuibeheer van de Stevinsluis (glasaalmaatregel) zal er minder glasaal vanuit de spuikom naar de schutkom zwemmen. 


\section{Materiaal en methoden}

\subsection{Generieke aanpak}

Het in dit rapport beschreven onderzoek beslaat een onderzoeksperiode van 3 jaar: 2015, 2016 en 2017.

Het jaar 2015 vormde de 'nulmeting' omdat de vismigratie bevorderende maatregelen dan nog niet zijn ingevoerd. In 2016 en 2017 zijn maatregelen gefaseerd ingevoerd en de monitoring heeft in deze jaren tot doel de eventuele afwijking op de nul situatie te bepalen.

De monitoring richtte zich op het schatten van de hoeveelheid glasaal, de verspreiding in het gebied en de verblijftijd in de gebieden. Om dit te kunnen schatten is onder meer gebruikt gemaakt van zgn. kleuringsproeven, waarbij glasaal wordt gevangen- gekleurd en weer wordt teruggezet. Op volgende avonden werd wederom glasaal gevangen. De aantallen gekleurde glasalen die de daaropvolgende dagen worden terug gevangen geven een indicatie van de verblijftijd van de glasalen in het gebied.

De veldwerkzaamheden zijn in elk onderzoeksjaar uitgevoerd tussen 1 maart en 1 juni, de periode dat de meeste glasalen in het onderzoeksgebied aanwezig zijn, en omvat tevens de periode waarin de reguliere bemonsteringen voor het bepalen van de glasaal index worden uitgevoerd.

Omdat glasaal vooral in het donker en tijdens opkomend tij actief is, zijn de veldproeven op deze momenten uitgevoerd. Zo konden per jaar maximaal 6 werkperioden van elk 3- 6 nachten worden geselecteerd, telkens met een tussenliggende periode van ca. 14 dagen in verband met het verloop van het getij. Op basis van de vangsten van de glasaalindex-vissers werd bepaald of glasaal in het gebied aanwezig was, en wanneer de monitoring effectief uitgevoerd kon worden.

Het streven was om tijdens de eerste nacht van elke monitoringsperiode zoveel mogelijk glasaal te vangen, en na kleuring (Figuur 5) met de kleurstof Bismarck Brown ( $0.05 \mathrm{gr} / \mathrm{L}$ ) weer in het vangstgebied los te laten. Het aantal glasalen is bepaald door minimaal 5 porties van 100 alen uit te tellen en te wegen. Vervolgens wordt het totaal gewicht van de gevangen glasaal (voor kleuring) bepaald, en omgerekend hoeveel stuks dat zijn om uit te zetten.

De daaropvolgende nachten is de verspreiding van deze gekleurde alen en van niet gekleurde aal in het onderzoeksgebied gemonitord volgens een vast raster. De kleuring is zeker een week zichtbaar en na 14 dagen voldoende van de visjes verdwenen of vervaagd om onderscheid met een nieuwe groep te maken (Foekema et al., 2014). Door alleen duidelijk gekleurde alen als 'gekleurd' te beschouwen worden geen 'oude' gekleurde alen meer gesignaleerd in opvolgende monitoring periodes.

Deze opzet geeft een indicatie in de verdeling en verblijftijd van glasaal in het onderzochte gebied.

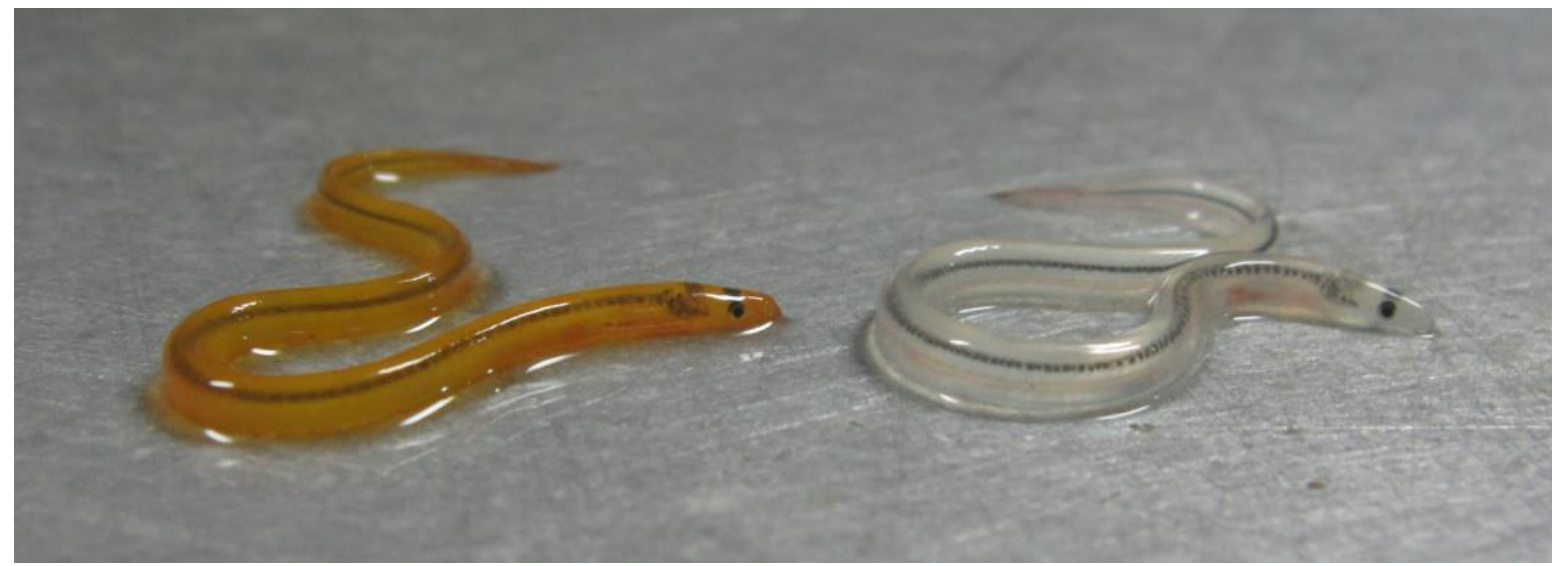

Figur 5 Gekleurde glasaal (links) en niet gekleurde glasaal (rechts) 
Bij de uitvoering van de bemonsteringen werd WMR bijgestaan door Bram van Wijk van Visserij Service Nederland, en de gebroeders van Malsen (WON1).

In elk jaar zijn de monitoringsdata van de glasaalindex opgevraagd. Deze data zijn met de vangsten van de merk-terugvangexperimenten vergeleken. In de uitwerking van de data-analyse wordt meer detail gegeven.

In 2015 en 2016 werden de bemonsteringen gelijktijdig in de spuikom en in de schutkom uitgevoerd. Waarbij afwisselend aan het begin van de bemonsteringsperiode in de spuikom of in de schutkom gekleurde glasalen werden uitgezet die in hetzelfde gebied waren gevangen. De gemerkte glasalen waren afkomstig van ofwel de schutkom (en dus ook uitgezet in de schutkom), ofwel de spuikom (en dus ook uitgezet in de spuikom).

In 2017 is de schutkom niet gemonitord. De glasalen voor de kleuring voor de spuikom waren, in tegenstelling tot voorgaande jaren, afkomstig uit de schutkom. Dit was noodzakelijk omdat in voorgaande jaren was gebleken dat er in spuikom niet voldoende glasalen konden worden gevangen voor een zinvol merk terugvangst experiment. In Tabel 1 is een overzicht gegeven van de veldwerkzaamheden in de verschillende onderzoekjaren.

Tabel 1 Overzicht van de veldwerkzaamheden in de verschillende onderzoekjaren

\begin{tabular}{|c|c|c|c|}
\hline Periode & data & Spuikom & Schutkom \\
\hline \multicolumn{4}{|l|}{2015} \\
\hline 1 & 10 april & $\begin{array}{l}\text { Trawl onvoldoende voor } \\
\text { kleuring }\end{array}$ & \\
\hline 2 & 22 april & $\begin{array}{l}\text { Trawl onvoldoende voor } \\
\text { kleuring }\end{array}$ & \\
\hline \multirow[t]{2}{*}{3} & 26 april & & Ca. 12.336 st. gekleurd \\
\hline & 27-30 april & Monitoring & Monitoring \\
\hline \multirow[t]{2}{*}{4} & 11 mei & & Ca. 9.595 st. gekleurd \\
\hline & 12-15 mei & Monitoring & Monitoring \\
\hline 5 & 19-21 mei & Monitoring & Monitoring \\
\hline \multicolumn{4}{|l|}{2016} \\
\hline \multirow[t]{2}{*}{1} & 28 maart & Ca. 670 st. gekleurd & \\
\hline & 29-31 maart & Monitoring & Monitoring \\
\hline \multirow[t]{2}{*}{2} & 11 april & & Ca. 23.000 st. gekleurd \\
\hline & 12-14 april & Monitoring & Monitoring \\
\hline \multirow[t]{2}{*}{3} & $1 \mathrm{mei}$ & Ca. 1.200 st gekleurd & \\
\hline & 2-3 mei & Monitoring & Monitoring \\
\hline \multirow[t]{2}{*}{4} & 10 mei & & Ca 19.500 st. gekleurd \\
\hline & 11-13 mei & Monitoring & Monitoring \\
\hline \multicolumn{4}{|l|}{2017} \\
\hline \multirow[t]{2}{*}{1} & 1 april & Ca. 5.000 st. gekleurd ${ }^{1}$ & \\
\hline & 2-5 april & Monitoring & \\
\hline \multirow[t]{2}{*}{2} & 19 april & Ca. 14.300 st. gekleurd ${ }^{1}$ & \\
\hline & 20-23 april & Monitoring & \\
\hline \multirow[t]{2}{*}{3} & 2 mei & Ca. 17.600 st. gekleurd ${ }^{1}$ & \\
\hline & 3-7 mei & Monitoring & \\
\hline
\end{tabular}

1 glasaal afkomstig uit schutkom.

\subsection{Monitoring ontwerp spuikom}

De bemonsteringen in de spuikom zijn uitgevoerd vanaf een schip met een kruisnet van $3 \times 3 \mathrm{~m}$ langs een vast raster (Figuur 6). In 2015 is dit tijdens enkele nachten gecombineerd met bemonsteringen met een $1 \times 1 \mathrm{~m}$ kruisnet, met als doel verschillen in vangst efficiëntie vast te stellen. Het $1 \times 1 \mathrm{~m}$ kruisnet 
wordt namelijk standaard gebruikt bij de monitoring ten bate van de glasaal index. De aantallen gevangen glasalen worden per trek geteld en in elk monster wordt het aandeel gekleurde alen vastgesteld en genoteerd. In de spuikom is in 2015 ook enkele keren gevist met een fijnmazig trawlnet omdat de vangsten met het kruisnet heel bepekt bleken.

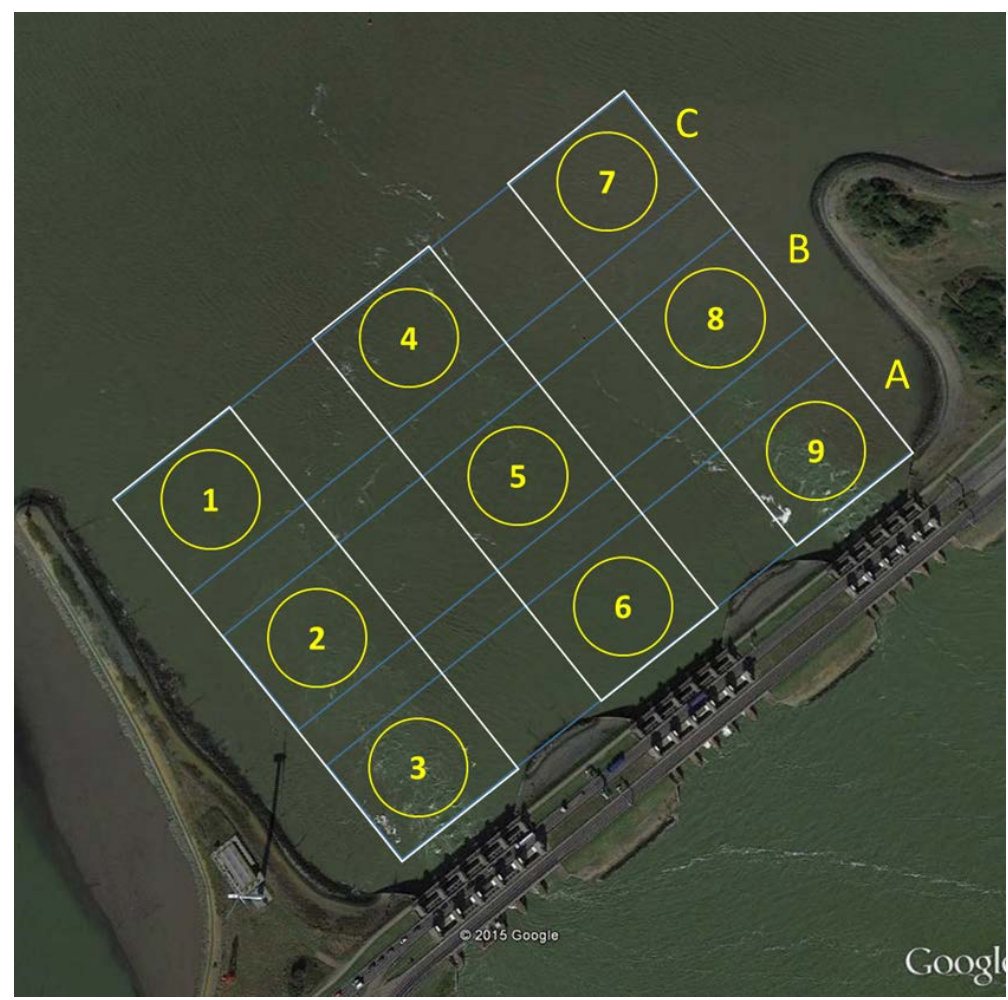

Figuur 6 Monster locaties in de spuikom (A, B, C zijn de afstand posities, 1-9 de individuele monster locaties)

In het voorjaar van 2015 was de visvriendelijke spui nog niet in werking, en de monitoring was bedoeld als een zgn. T0 meting. In 2015 waren de dichtheden glasaal in de spuikom echter bijzonder laag waardoor het voorgestelde merken en terugvangen van glasalen in de spuikom niet kon worden uitgevoerd. Vanwege de lage aantallen in zowel de monitoring als in de index vangsten, wordt 2015 niet als representatief jaar voor de spuikom gezien.

In 2016 was aanvankelijk gepland om onderzoek uit te voeren mèt de visvriendelijke spuimaatregelen in werking (T1). De noodzakelijke aanpassing van de Stevinsluis liep echter vertraging op waardoor in 2016 nog niet alle visvriendelijke maatregelen bij Den Oever konden worden doorgevoerd. De visvriendelijke maatregelen in de schutkom (hevelpassage en het extra schutten) vond doorgang, maar het visvriendelijk spuien ten behoeve van de glasaal intrek werd uitgesteld. Dit bood de gelegenheid om in 2016 in overleg met de opdrachtgever nogmaals een T0 meting in de spuikom uit te voeren. In 2016 zijn op 2 momenten gekleurde glasalen in de spuikom uitgezet (Figuur 7).

Het werkplan van 2017 was gericht op het uitvoeren van de T1 monitoring, om te bepalen of de ingestelde maatregelen (visvriendelijke spui) effect hebben op de index-aantallen, de verblijftijd en verdeling van glasaal in de spuikom. Omdat in voorgaande jaren duidelijk was geworden dat het niet mogelijk was om in de spuikom voldoende glasaal te vangen voor een zinvol merk-

terugvangexperiment zijn hiervoor in 2017 glasalen gevangen nabij de RWZI-uitlaat in de schutkom (de RWZI uitlaat gaat gepaard met een zoete lokstroom voor vis waardoor er nabij deze locatie relatief snel, relatief veel glasaal kan worden verzameld). Na kleuring zijn deze uitgezet in de spuikom op de locaties zoals aangegeven in Figuur 7. Monitoring heeft in opvolgende nachten plaatsgevonden in de spuikom.

$\mathrm{Er}$ is in 2017 niet simultaan gemonitord in de schutkom. Verplaatsing gekleurde glasaal van spuikom naar schutkom zou worden gemonitord middels het geplande onderzoek aan de vishevelpassage. De vispassage bleek echter frequent in storing te zijn, en onderzoek heeft daar niet plaatsgevonden. 


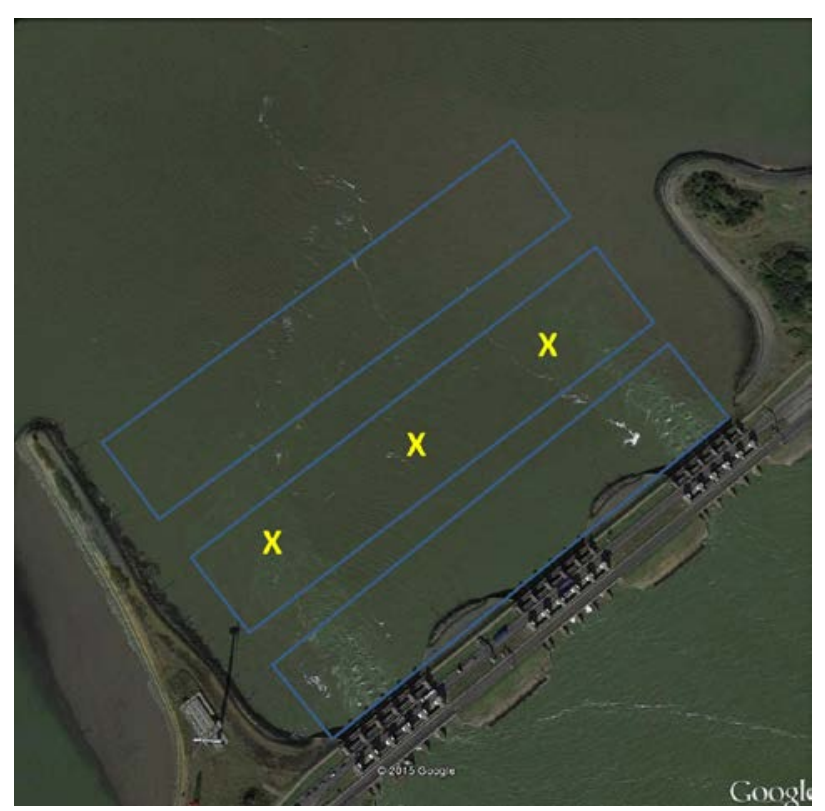

Figuur 7 Posities waar gekleurde glasaal is uitgezet in de spuikom.

In de loop van voorjaar 2017 bleek dat de visvriendelijke spuimaatregel wél op 22 december 2015 in werking is getreden. Ten tijde van het onderzoek in 2016 was dit echter niet bekend voor het onderzoeksteam en is het niet mogelijk geweest het onderzoek aan te passen. Achteraf is 2016 dus géén extra T0 monitoring gebleken, maar een T1 monitoring. Op 16 april 2016 is het visvriendelijke spuibeheer bovendien voor onbepaalde tijd stopgezet, maar niet gecommuniceerd naar WMR. Het visvriendelijke spuibeheer vond in de periode tussen april 2016 en 2017 alleen plaats als er dienstwachters aanwezig waren met deze bevoegdheid. Het is echter niet bekend wanneer deze dienst hadden, en wanneer de glasaalspui wel of niet in werking was. Alleen in direct afgestemde periodes waarin er tussen WMR en de dienstwacht persoonlijk en direct contact is geweest over de instellingen kan met redelijke zekerheid worden verondersteld wat de status van de maatregelcombinatie is geweest. In 2017 betreft dit 3 periodes van een aantal dagen waarin de merk terugvangst experimenten werden uitgevoerd.

Met het ontbreken van de cruciale informatie over spui-instellingen in combinatie met visvriendelijke spuimaatregelen is het niet mogelijk om alle index-monitoringsdata te koppelen. De datadichtheid is sterk beperkt tot de 3 afgestemde periodes in 2017.

\subsection{Monitoring ontwerp schutkom}

De bemonsteringen in de schutkom zijn uitgevoerd vanaf een schip met een kruisnet van $1.5 \times 1.5 \mathrm{~m}$ en een kruisnet van $1 \times 1 \mathrm{~m}$ meter langs een vast raster (Figuur 8 ). 


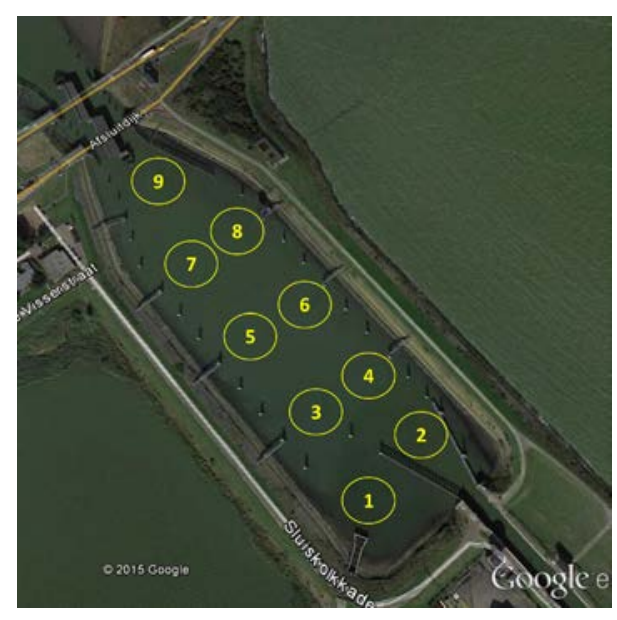

Figuur 8 Monsterlocaties in de schutkom

In beide jaren- 2015 (T0) en 2016 (T1) is tijdens twee monitoringsperiodes glasaal gekleurd en teruggezet (Tabel 1). In 2017 zijn geen glasaal bemonsteringen in de schutkom uitgevoerd. 


\section{$4 \quad$ Beschikbare data en analysemethoden}

\subsection{Spuikom}

De volgende data en informatie is beschikbaar (samengevat in Tabel 2).

\section{Indexmonitoring data (indexvissers)}

- Data beschikbaar voor alle jaren in de periode 1 maart- 31 mei.

- Elke nacht tussen 22:00 en 05:00 uur wordt op elk uur een visbemonstering gedaan met een kruisnet van $1 \times 1 \mathrm{~m}$ meter bij spuikoker $\mathrm{nr}$. 6 op het spuisluiscomplex. Het aantal gevangen glasaal, en het aantal gekleurde aal (indien van toepassing) wordt genoteerd.

Merk-terugvangst experiment monitoring data

o Data beschikbaar voor geselecteerde periodes in 2015, 2016 en 2017 van aantal gevangen glasaal op 9 locaties in de spuikom, inclusief eventueel gekleurde glasaal.

\section{RWS Logboek data spui instellingen en visintrek}

- Voor 2016 en 2017 zijn de digitale logboek gegevens van de spuiregimes van de spuisluizen ter beschikking gesteld door RWS. Uit de logboeken kan worden opgemaakt wanneer er is gespuid (tijdperiode per dag), en of dit samen ging met de visintrekmaatregel. Er is in de digitale logboeken geen melding gemaakt of het visvriendelijk spuibeheer (glasaalmaatregel) is uitgevoerd. Op basis van de algemene regel- dat het visvriendelijk spuibeheer voorafgaand aan de reguliere visintrek-maatregel (communicatie Van der Veen, RWS) is in de dataverwerking aangenomen dat de glasaal-maatregel altijd werd toegepast in combinatie met de visintrek-maatregel.

- Dit leidt tot de volgende mogelijke combinaties van spuiregime en visintrek en glasaalmaatregelen:

o Spui (-); visintrek (-); glasaalmaatregel (-)

o Spui (-); visintrek (+); glasaalmaatregel $(+)$

o Spui (+); visintrek (-); glasaalmaatregel (-)

o Spui $(+)$; visintrek $(+)$; glasaalmaatregel (-)

o $\quad$ Spui (+); visintrek $(+)$; glasaalmaatregel (?)

o $\quad$ Spui (+); visintrek (+); glasaalmaatregel (+)

o Wisselend: dit betekent dat tijdens de 24 uur voorafgaand aan de monitoring of indexvangst het regime wijzigde.

- De instelling 24 uur voorafgaand aan de bemonsteringsperiode (t.b.v. van de glasaalindex of merk terugvangst experiment) is bepalend voor de koppeling aan de vangstdata.

Tabel 2 Samenvattend overzicht van beschikbare data Spuikom

\begin{tabular}{|c|c|c|c|}
\hline jaar & Index monitoringdata & Merk terugvangst experiment & $\begin{array}{l}\text { Instelling spuiregime } \\
\text { en vismaatregelen }\end{array}$ \\
\hline 2015 & $a$ & Nee & Nee \\
\hline 2016 & $\mathrm{a}$ & $\begin{array}{l}\text { a, beperkt uitgezette aantallen, } \\
\text { enkele terugvangsten. }\end{array}$ & $\begin{array}{l}\text { Beperkt en grotendeels } \\
\text { onduidelijkheid over } \\
\text { instelling. }\end{array}$ \\
\hline 2017 & $a$ & $\begin{array}{l}\text { a, } \sim 20.000 \text { gekleurde uitgezet, } \\
\text { meerdere terugvangsten }\end{array}$ & $\begin{array}{l}\text { Beperkt tot periodes van } \\
\text { merk terugvangst } \\
\text { experiment. }\end{array}$ \\
\hline
\end{tabular}


Tabel 3 Gedetailleerd overzicht van spui instellingen in de spuikom, en uitgevoerde monitoring in de periodes in 2015- 2016 en 2017.

\begin{tabular}{|c|c|c|c|}
\hline Periode & Data & Spuikom & Spui en visintrek-instelling \\
\hline \multicolumn{4}{|l|}{2015} \\
\hline 1 & 10 april & $\begin{array}{l}\text { Trawl onvoldoende } \\
\text { voor kleuring }\end{array}$ & \multirow{7}{*}{$\begin{array}{l}\text { Heel 2015: } \\
\text { Onduidelijk spui en visintrek } \\
\text { regime, geen glasaal }\end{array}$} \\
\hline 2 & 22 april & $\begin{array}{l}\text { Trawl onvoldoende } \\
\text { voor kleuring }\end{array}$ & \\
\hline \multirow[t]{2}{*}{3} & 26 april & & \\
\hline & 27-30 april & Monitoring & \\
\hline \multirow[t]{2}{*}{4} & 11 mei & & \\
\hline & 12-15 mei & Monitoring & \\
\hline 5 & 19-21 mei & Monitoring & \\
\hline \multicolumn{4}{|l|}{2016} \\
\hline \multirow[t]{2}{*}{1} & 28 maart & Ca. 670 st. gekleurd & Spui + visintrek + glasaal \\
\hline & 29-31 maart & Monitoring & Spui, geen vis, geen glasaal \\
\hline \multirow[t]{2}{*}{2} & 11 april & & Wisselend \\
\hline & 12-14 april & Monitoring & Wisselend \\
\hline \multirow[t]{2}{*}{3} & 1 mei & Ca. 1.200 st. gekleuro & \multirow{2}{*}{$\begin{array}{l}\text { Deels niet gespuid, deels wel. } \\
\text { Visintrek geopend. Onduidelijk } \\
\text { of glasaalmaatregel is ingesteld. }\end{array}$} \\
\hline & 2-3 mei & Monitoring & \\
\hline \multirow[t]{2}{*}{4} & $10 \mathrm{mei}$ & & \multirow{2}{*}{$\begin{array}{l}\text { Wisselend spui, visintrek wel } \\
\text { open. Onduidelijk of } \\
\text { glasaalmaatregel is ingesteld. }\end{array}$} \\
\hline & 11-13 mei & Monitoring & \\
\hline \multicolumn{4}{|l|}{2017} \\
\hline \multirow[t]{2}{*}{1} & 1 april & \multicolumn{2}{|c|}{$\begin{array}{l}\text { Ca. } 5.000 \text { st. gekleurd } \begin{array}{l}\text { Spui open, visintrek, geen } \\
\text { glasaalintrek }\end{array} \\
\end{array}$} \\
\hline & 2-3 april & Monitoring & $\begin{array}{l}\text { Spui dicht, visintrek + glasaal in } \\
\text { werking }\end{array}$ \\
\hline \multirow[t]{2}{*}{2} & 19 april & $\begin{array}{l}\text { Ca. } 14.300 \text { st. } \\
\text { gekleurd }\end{array}$ & \\
\hline & 20-23 april & Monitoring & $\begin{array}{l}\text { Spui wisselend, visintrek + } \\
\text { glasaal in werking }\end{array}$ \\
\hline \multirow[t]{2}{*}{3} & 2 mei & $\begin{array}{l}\text { Ca. } 17.600 \text { st. } \\
\text { gekleurd }\end{array}$ & \\
\hline & 3-7 mei & Monitoring $^{2}$ & $\begin{array}{l}\text { Spui open, + visintrek, geen } \\
\text { glasaal in werking }\end{array}$ \\
\hline
\end{tabular}

De index- data van 2015 zijn door het ontbreken van gegevens van het spuiregime, en al dan net ingestelde visvriendelijke maatregelen niet goed te correleren. Bovendien werd er in 2015 in de spuikom erg weinig glasaal gevangen, onvoldoende voor merk terugvangst experimenten. Voor de analyse hebben de spuikom resultaten van 2015 daardoor weinig waarde en zijn buiten beschouwing gelaten.

Bij de uitwerking van de gegevens bleek dat de uitvoering van de visvriendelijke maatregelen niet consequent wordt geregistreerd in de logboeken "journaals" van de sluiswachters.

In deze logboeken is per handeling betreffende het sluiscomplex een notitie gemaakt. Dit levert per dag data over spui-tijden en spuistanden, soms inclusief opmerkingen over visvriendelijke intrek. In een aantal gevallen zijn deze notities niet volledig. Gegevens over visvriendelijk spuibeheer staat niet

\footnotetext{
${ }^{2}$ In 2017 periode 2, de monitoring langer monitoring aangehouden om te onderzoeken tot hoelang de alen in de spuikom zouden verblijven indien de maatregelen in werking was. In periode 3 van 2017 was de glasaalmaatregel niet in werking, en was de hypothese dat bij "dichte deuren" de glasaal een langere verblijftijd zouden hebben dan in vorige periode werd gezien. Monitoring is in periode 3 na T5 gestopt omdat kleuring onduidelijk werd, en nagenoeg geen alen meer werden gevangen
} 
vermeld in deze journaals. Omdat de glasaal-maatregel (visvriendelijk spuibeheer) in de uitvoering gekoppeld wordt aan de reguliere vistrekmaatregel is deze voor de data-analyse aan elkaar

gekoppeld. Dus, als de visintrek-maatregel werd uitgevoerd, dan is verondersteld dat ook de glasaalmaatregel werd uitgevoerd. Als er geen visintrek-maatregel is uitgevoerd, is aangenomen dat er ook geen glasaal maatregel werd uitgevoerd.

Ten tijde van de glasaalmonitoring in maart/april 2017 werd door RWS gemeld dat de glasaal-migratie bevorderende maatregelen tijdelijk werden stilgelegd omwille van veiligheidsredenen. Achteraf blijkt dat de maatregel onder bepaalde omstandigheden wel werd toegepast. Onduidelijk is echter wanneer dat precies is geweest. Voor de gehele periode is dus geen zekerheid, en is alleen de data van de spuijournaals en de notities van de indexvissers beschikbaar om de analyses op te baseren. Daarnaast is voor 2 periodes waarvoor specifieke afstemming is geweest over de glasaal-maatregel zeker wat de instelling was. In 2017 is alleen voor periode 1 een onzeker regime gevoerd. Naar alle waarschijnlijkheid was de maatregel wél ingesteld maar dit is niet herbevestigd door de sluiswachter.

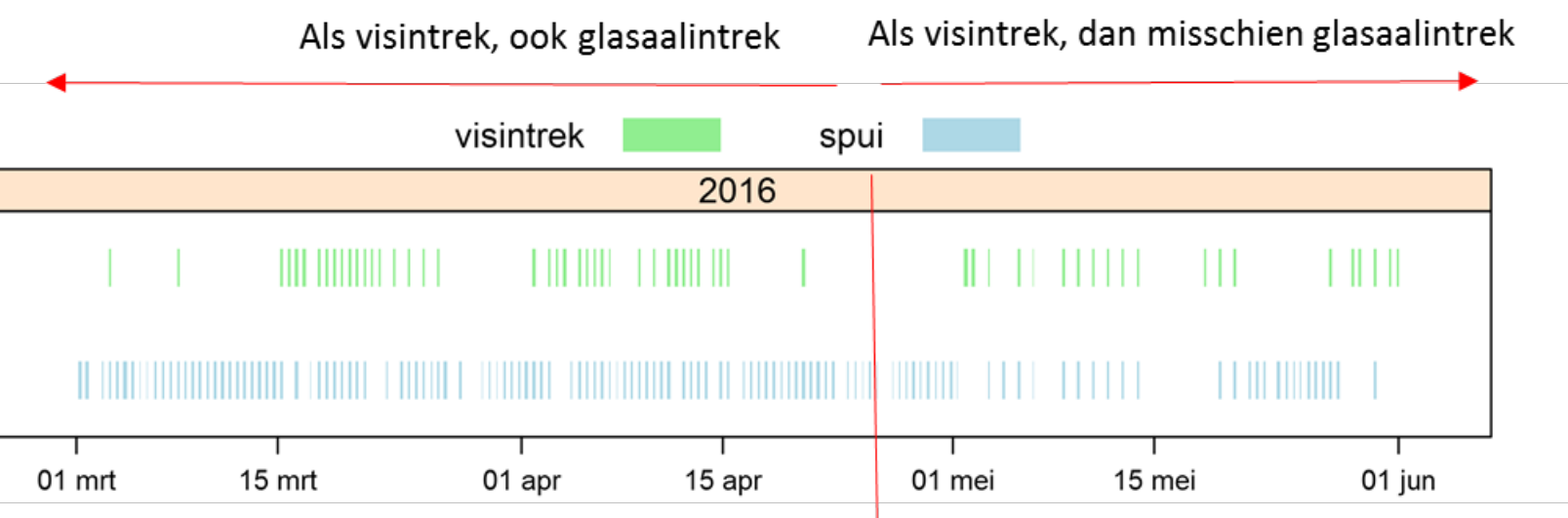

Als visintrek, dan misschien glasaalintrek, behalve op afgestemde periodes

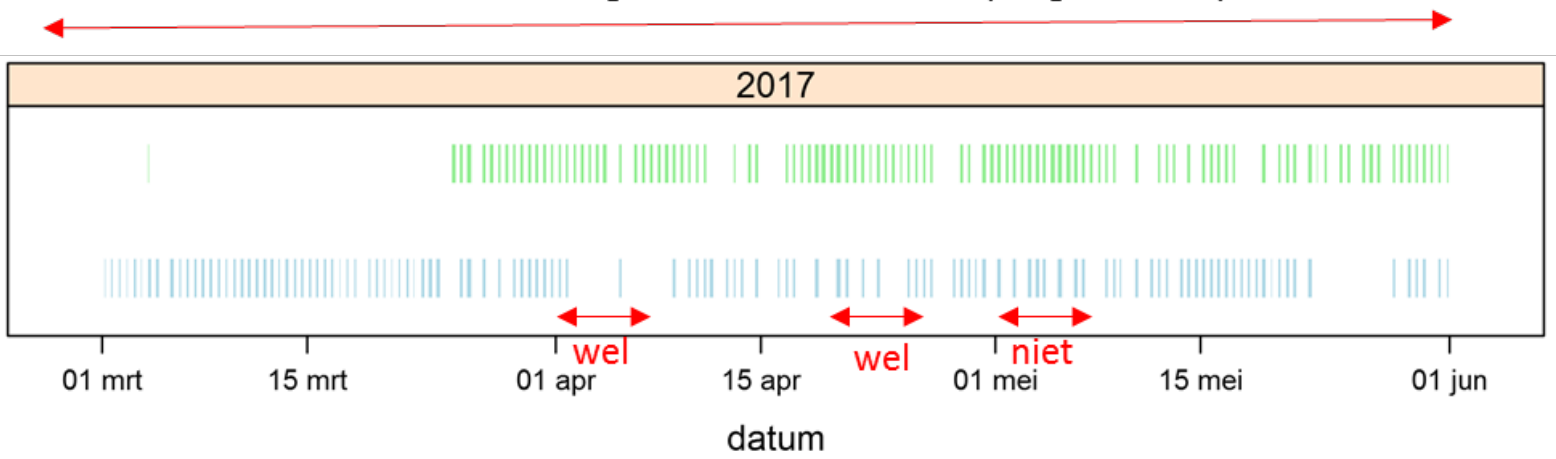

Figuur 9 Spui- en visintrek-momenten. Alleen momenten waarbij zowel start- als eindtijd gegeven zijn, zijn weergegeven. De periodes in 2017 waarin de glasaal mogelijk was omdat de maatregel 'wel' of 'niet' is ingesteld is met de rode pijlen extra aangegeven. Visintrek = "visspuien"

Tabel 4 Aantal metingen (individuele $3 \times 3 \mathrm{~m}$ en $1 \times 1 \mathrm{~m}$ kruisnet vangsten) ten bate van merk terugvangst experiment-monitoring per combinatie van spui, visintrek en glasaalmaatregel.

\begin{tabular}{|c|c|c|c|c|}
\hline Jaar & $\begin{array}{c}\text { Spui(-), } \\
\text { visintrek (+), } \\
\text { glasaal (+) }\end{array}$ & $\begin{array}{c}\text { Spui(+), } \\
\text { visintrek (+), } \\
\text { glasaal (-) }\end{array}$ & $\begin{array}{c}\text { Spui(+), } \\
\text { visintrek (+), } \\
\text { glasaal (+) }\end{array}$ & $?$ \\
\hline 2015 & 0 & 0 & 0 & 315 \\
\hline 2016 & 54 & 0 & 54 & 458 \\
\hline 2017 & 108 & 216 & 108 & 0 \\
\hline
\end{tabular}


Tabel 5 Aantal metingen (individuele $1 \times 1 \mathrm{~m}$ kruisnet vangsten) ten bate van index-monitoring per jaar per combinatie van spui, visintrek en glasaalmaatregel

\begin{tabular}{|c|c|c|c|c|c|}
\hline Jaar & $\begin{array}{c}\text { Spui(-), } \\
\text { visintrek (+), } \\
\text { glasaal (+) }\end{array}$ & $\begin{array}{c}\text { Spui(+), } \\
\text { visintrek (+), } \\
\text { glasaal (-) }\end{array}$ & $\begin{array}{c}\text { Spui(+), } \\
\text { visintrek (+), } \\
\text { glasaal (+) }\end{array}$ & $\begin{array}{c}\text { Spui(+), } \\
\text { visintrek (-), } \\
\text { glasaal (-) }\end{array}$ & $?$ \\
\hline 2015 & 84 & 0 & 16 & 32 & 570 \\
\hline 2016 & 131 & 51 & 39 & 0 & 498 \\
\hline 2017 & & & & & \\
\hline
\end{tabular}

\subsection{Schutkom}

Voor de schutkom zijn de volgende data beschikbaar

Merk-terugvangexperiment monitoring data

- Vangsten (totaal en gekleurde fracties) tijdens een viertal merk-terugvangst experimenten in 2015 en 2016. De data zijn gebaseerd op 279 trekken totaal in 2015 en 342 trekken totaal in 2016. In Tabel 6) staat een overzicht van de uitgevoerde monitoring per periode in de schutkom.

Hevelpassage data

- Vishevel onderzoek 2016: De effectiviteit van de vishevel is gemonitord door de ontwerper van het systeem FishFlow innovations te Medemblik. Vanaf 12 april 2016 is het totaal aantal gepasseerde glasaal per dag, inclusief aantal gekleurden bepaald.

\section{Schutsluis gegevens}

- $\quad$ Er zijn geen gegevens beschikbaar over het aantal schuttingen van de schutsluis. Volgens RWS waren er in het voorjaar van 2015 nog geen visvriendelijke maatregelen van kracht rond Den Oever. Dit betekent dat er in 2015 geen en in 2016 wel loze schuttingen zouden zijn uitgevoerd, exacte gegevens ontbreken echter en staan niet vermeld in de journaals van RWS.

Tabel 6 Gedetailleerd overzicht van uitgevoerde monitoring in de periodes in 2015 en 2016 in de schutkom.

\begin{tabular}{|c|c|c|c|}
\hline Periode & data & Schutkom & Vismigratiemaatregelen \\
\hline \multicolumn{4}{|l|}{2015} \\
\hline 1 & 10 april & Monitoring & \multirow{4}{*}{$\begin{array}{l}\text { Nog geen vismigratiemaatregelen } \\
\text { in werking in de schutkom. }\end{array}$} \\
\hline 2 & 22 april & Monitoring & \\
\hline \multirow[t]{2}{*}{3} & 26 april & $\begin{array}{l}\text { Ca } 12.336 \text { st gekleurd } \\
\text { schutkom }\end{array}$ & \\
\hline & 27-30 april & Monitoring & \\
\hline 4 & 11 mei & $\begin{array}{l}\text { Ca. } 9.595 \text { st gekleurd } \\
\text { schutkom }\end{array}$ & \multirow{3}{*}{$\begin{array}{l}\text { Kleuring in spuikom, en } \\
\text { aansluitend ook monitoring in } \\
\text { schutkom (periode } 1,2,5 \text { ) } \\
\text { Kleuring in schutkom in periode } 3 \\
\text { en } 4 .\end{array}$} \\
\hline & 12-15 mei & Monitoring & \\
\hline 5 & 19-21 mei & Monitoring & \\
\hline
\end{tabular}




\begin{tabular}{|l|l|l|l|}
\hline Periode & data & Schutkom & Vismigratiemaatregelen \\
\hline $\mathbf{2 0 1 6}$ & & & \\
\hline 1 & 28 maart & $\begin{array}{l}\text { Gekleurd in spuikom } \\
(670 \text { st. })\end{array}$ & Heel 2016: \\
\hline 2 & $29-31$ maart & $\begin{array}{l}\text { Monitoring } \\
\text { Ca } 23.000 \text { st gekleurd } \\
\text { schutkom }\end{array}$ & $\begin{array}{l}\text { schuttingen in werking. Geen } \\
\text { registratie van hoeveelheid extra } \\
\text { schuttingen. }\end{array}$ \\
\hline 3 & 11 april & $\begin{array}{l}\text { Monitoring } \\
\text { Ca. } 1.200 \text { st gekleurd } \\
\text { spuikom }\end{array}$ & \\
\hline 4 & $12-14$ april & Monitoring & \\
\hline & 1 mei & Ca 19.500 st gekleurd & \\
\hline & $2-3$ mei & Monitoring & \\
\hline
\end{tabular}

\subsection{Databewerking}

\subsubsection{Koppeling vangstwaarnemingen aan spuiregime}

Zoals vermeld gaven de via RWS verkregen gegevens over de bediening van de sluisluizen niet altijd een compleet beeld van de situatie. Wel is duidelijk wanneer er met spuien is begonnen en regelmatig is aangegeven dat de visintrekmaatregel al dan niet werd toegepast. Echter, van de glasaalmaatregel is slechts voor een beperkt aantal monitoringsperioden bekend of de maatregel inderdaad werd toegepast (maar niet precies wanneer actief). In een aantal gevallen is alleen bekend wanneer het spuien, dan wel de visintrekmaatregel, is gestart, maar niet wanneer deze is beëindigd.

In die gevallen is een onzekere periode gedefinieerd op basis van de overige gegevens. Zo is bepaald dat er in meer dan 90\% van de gevallen langer dan 2 uur, maar korter dan 6 uur wordt gespuid. Als de sluitingstijd van de spuisluis niet bekend is, is dus aangenomen dat tot 2 uur na opening, er vrijwel zeker werd gespuid. Daarna is het onzeker. Maar 6 uur na opening wordt aangenomen dat het spuien vrijwel zeker is beëindigd. Voor de visintrek ligt de onzekere periode tussen 8 en 54 minuten na opening van de visintrek.

De glasaalbemonsteringen (zowel voor de index als voor het merk- terugvangexperiment) zijn gekoppeld aan het spuiregime dat op het moment van de bemonstering en in de periode 24 uur voorafgaand van de bemonstering actief was. Wanneer een maatregel in die 24 uursperiode actief was, wordt dit ook zo toegekend aan de bemonstering. Als een maatregel in de gehele 24 uursperiode niet actief was, is dit ook zo toegekend aan de waarneming. Als er onduidelijkheid of onzekerheid is over een maatregel, is dit ook zo toegekend aan de waarneming.

\subsubsection{Bepalen gevangen fracties in de ruimte (spui- en schutkom)}

Om een beeld te krijgen van de verdeling van de glasaal over de ruimte in de schutkom, zijn de bemonsteringslocaties die veel op elkaar lijken (qua aantallen gevangen glasaal per trek) gegroepeerd. Hiertoe is een clusteranalyse toegepast.

Voor de spuikom zijn de verschillen tussen de posities op dezelfde rij minimaal. Voor de analyse worden posities daarom gegroepeerd. Er is beoordeeld hoe de glasaal zich verdeeld over de rijen A, B en C (Figuur 6), die in deze volgorde corresponderen met de afstand van tot de sluis.

Alle bemonsteringspunten zijn in vaste volgorde bemonsterd, waarbij de monstering per sessie een aantal maal is herhaald. Voor elke reeks waarin alle posities zijn bemonsterd is het gemiddeld aantal gevangen glasaal berekend voor alle ruimtelijke groepen (posities $1 ; 2+3$ en 4 tot en met 9 voor de schutkom; en rijen A, B en C voor de spuikom). Vervolgens is deze gemiddelde vangst gedeeld door de som van alle locatie groepen. Zo is bekend hoe voor die bemonsteringsreeks de glasaal verdeeld is over de ruimte. De totale fractie van alle posities moet gelijk zijn aan 1. 


\subsubsection{Correlatie vangsten index monitoring en merk-terugvang-experiment}

Ten behoeve van de correlatie tussen de vangsten van de index-vissers en het monitoringsonderzoek in de spuikom zijn eerst de aantallen gevangen glasalen per trek per dag gemiddeld, voor zowel de index-trekken ( $1 \times 1 \mathrm{~m}$ net) als de trekken voor het merk-terugvangexperiment ( $3 \times 3 \mathrm{~m}$ net). Hierbij is een dag beschouwd als lopend van 8 uur 's ochtends tot 8 uur 's ochtends op de volgende dag. Vervolgens zijn de gemiddelde index-vangsten van dezelfde dag bepaald en gekoppeld aan de gemiddelde vangsten van de terugvangstmonitoring op dezelfde dag.

Bij de analyse van de invloed van het spuibeheer is de spuistand en visintrekstand horend bij de terugvangstmonitoring als leidend gebruikt wanneer het regime bij de index gegevens afwijkt.

\subsubsection{Statistiek}

\section{Regressie/ anova (spuikom)}

Om vast te stellen of er een relatie bestaat tussen de glasaalvangsten en spui- en visintrek stand zijn regressie/anova analyses uitgevoerd op de daarvoor geschikte data.

In 2016 en 2017 varieert het aantal scenario's in spui en visintrekstanden in de perioden waarin de experimenten zijn uitgevoerd en is er onvoldoende overlap in gegevens om de effecten van elke individuele stand in het spuicomplex vast te stellen. De gegevens kunnen daarom niet worden gebruikt om vast te stellen of er een variatie over de jaren is op het effect van spuiregime op de ruimtelijke verdeling van glasaal. Statistische analyses zijn derhalve op de afzonderlijke jaren toegepast.

Effecten van de afstand tot de spuisluis op de verdeling over de ruimte zal ook niet worden getoetst. Dit omdat de verdeling over de ruimte is berekend als de fractie op een bepaalde plaats ten op zichtte van het totaal op alle plaatsen. De waarnemingen bij de verschillende afstanden zijn dus niet onafhankelijk van elkaar. Voor de analyse gebruiken we daarom alleen de berekende fractie gevangen glasaal op positie A (nabij de sluis). Als er een effect is van spuiregime op deze fractie, betekent dat automatisch een effect op de verdeling over de ruimte.

Dit wordt getoetst met een ANOVA, waarbij de fractie gevangen glasaal (op positie A) wordt verklaard aan de hand van het spuiregime (gekoppeld aan de bemonstering zoals hierboven beschreven). Omdat deze fracties altijd tussen de 0 en de 1 liggen en daarmee niet normaal verdeeld zijn, zal de analyse niet voldoen aan de randvoorwaarden bij een ANOVA analyse. Resultaten uit de analyse moet derhalve als indicatief worden beschouwd. Wanneer er een significant effect van het spuiregime wordt gevonden, wordt de post-hoc 'Tukey honest significant difference test' toegepast. Deze test wordt gebruikt om te bepalen welk spuiregime leidt tot een significant verschillende verdeling van glasaal over de ruimte. Ook deze toets zal om hiervoor genoemde reden als indicatief moeten worden beschouwd.

\section{Regressie/ anova (schutkom)}

In de schutkom zijn er verschillende factoren die de ruimtelijke verdeling van de glasaal hebben kunnen beïnvloeden. Omdat veel veranderingen plaatsvonden van het jaar 2016 op het jaar 2017, is bepaald of de verdeling van glasaal in de ruimte is veranderd tussen deze jaren.

Net als bij de spuikom zijn de fracties glasaal op de verschillende locaties niet onafhankelijk. Er wordt daarom steeds 1 locatiegroep getoetst. Er wordt een ANOVA toegepast waarbij de fractie gevangen glasaal in de geselecteerde locatiegroep is veranderd over de jaren heen. 'Jaar' is daarmee een verklarende variabele, welke als factor (en dus niet numeriek) wordt meegenomen in het model. Omdat er slechts twee jaren vergeleken worden, is het niet nodig om een post-hoc test uit te voeren. Net als bij de spuikom moet de ANOVA analyse als indicatief worden beschouwd. 


\section{$5 \quad$ Resultaten}

\section{$5.1 \quad$ Spuikom}

\subsubsection{Glasaalvangsten in indexmonitoring}

In de jaren 2015, 2016 en 2017 is tijdens de indexmonitoring een gelijke inspanning gedaan in het aantal halen (Tabel 7). De glasaalvangst tussen de jaren is echter zeer uiteenlopend. De vangsten, zowel de gemiddelde vangst, als het totaal over het seizoen, in 2015 waren zeer laag, en het percentage nulmetingen (waarbij geen aal is gevangen) 78\% was. De opvolgende jaren werd meer glasaal gevangen, en was het percentage nulmetingen aanzienlijk lager. Dit indiceert een hoger aantal glasaal in de spuikom dan in 2015. Het maximum aantal gevangen glasaal per haal stijgt over de jaren mee.

Tabel 7 Analyse van de aantallen glasaal gevangen tijdens de monitoringssessies ten bate van de glasaal index in de jaren 2015, 2016 en 2017

\begin{tabular}{|l|c|c|c|}
\hline & $\mathbf{2 0 1 5}$ & $\mathbf{2 0 1 6}$ & $\mathbf{2 0 1 7}$ \\
\hline Totaal aantal halen & 722 & 726 & 728 \\
Totale vangst & 265 & 666 & 1432 \\
$\%$ 'nul metingen' & $78 \%$ & $64 \%$ & $47 \%$ \\
\hline Per haal & & & \\
Gemiddeld per trek \pm st.dev. & $0.37 \pm 0.93$ & $0.92 \pm 1.94$ & $1.97 \pm 3.95$ \\
15\% Percentile & 0 & 0 & 0 \\
Median & 0 & 0 & 1 \\
85\% Percentile & 1 & 2 & 4 \\
Maximum & 11 & 22 & 40 \\
\hline
\end{tabular}

Bij het verwerken van de index-data viel het op dat er in uren dat er daadwerkelijk gespuid wordt minder glasaal wordt gevangen (Figuur 10). Omdat de index-monitoring direct achter de sluis wordt uitgevoerd kan deze observatie erop duiden dat de meeste glasaal door de waterkracht tijdens het spuien wordt weggedreven.

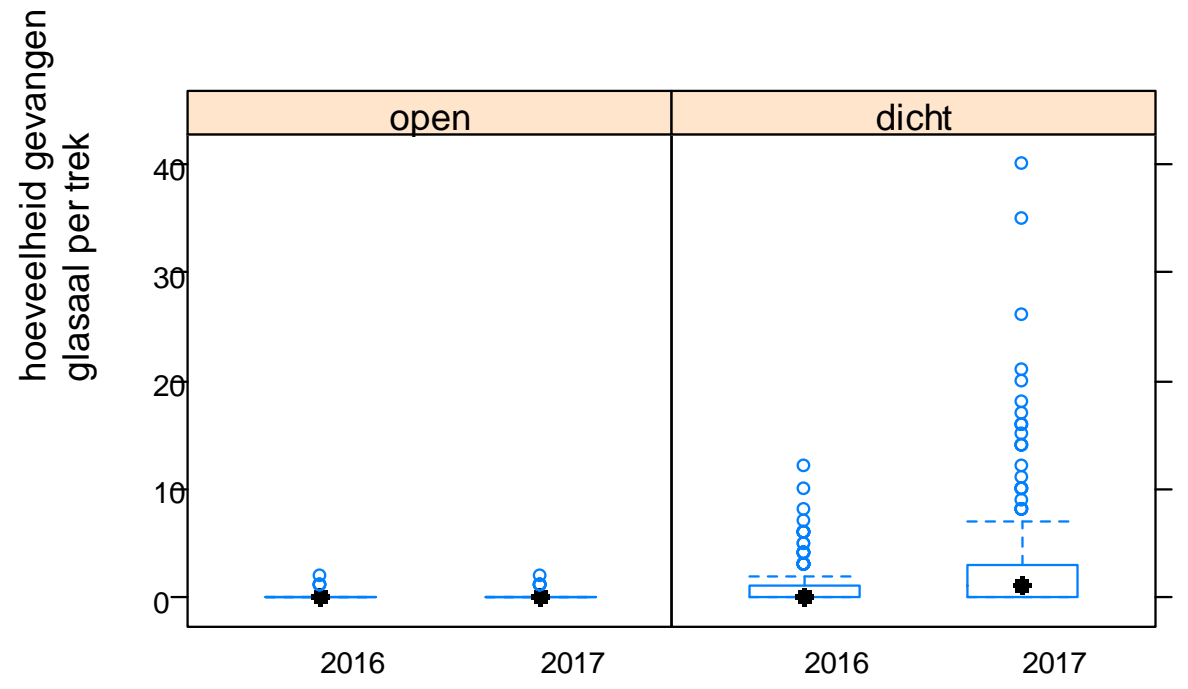

Figuur 10 Gevangen glasaal per trek in de index-monitoring tijdens spuien (open) en niet spuien (dicht). 


\subsubsection{Kruisnet bemonstering}

In de spuikom werden in 2015 zes, in 2016 negen en in 2017 acht nachten met een 3x3m kruisnet bemonsteringen uitgevoerd, hierbij werden in totaal respectievelijk 381, 9532 en 5529 glasalen gevangen. De hoogste aantallen per trek werden gevangen in de eerste helft van april in 2016 en 2017. In 2015 waren de aantallen glasalen van de index-vissers laag tot aan half april (Figuur 11). Toen de index vissers ook ná half april 2015 nog steeds lage aantallen glasalen per trek bleven vangen is besloten de kruisnetbemonsteringen in de spuikom toch uit te voeren om niet het hele seizoen te missen. De bemonsteringen van 2015 werden daarom uitgevoerd rond eind april tot half mei. In zowel 2016 als 2017 kwam de trek eerder op gang, en hield deze ook langer aan, en kon de monitoring over een langere periode plaatsvinden.

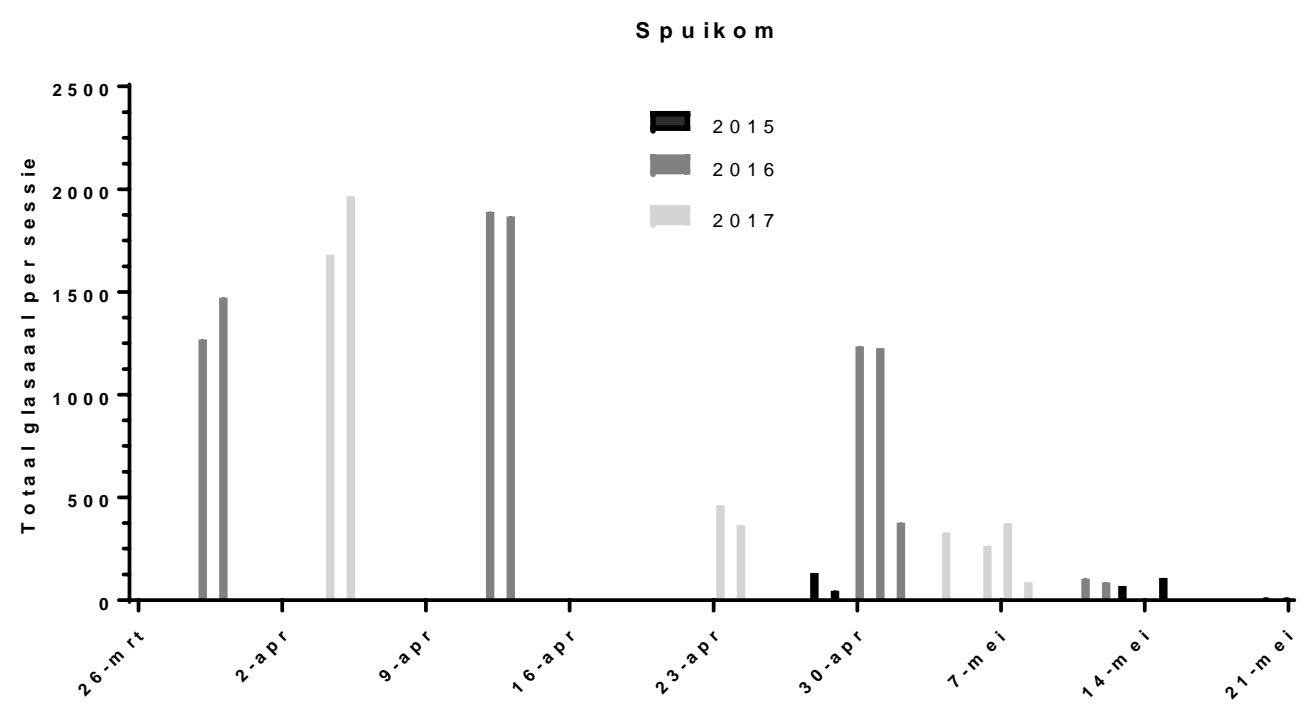

Figuur 11 Overzicht van het totaal aantal gevangen glasalen per bemonsteringssessie in de spuikom in de jaren 2015, 2016 en 2017.

In 2015 werden de laagste aantallen glasaal gevangen met een gemiddelde van < 3 alen per trek en een maximum aantal van 25. In 2016 en 2017 lagen deze aantallen beduidend hoger en werden soms meer dan 100 alen per trek gevangen (Figuur 12). Uit de vangstgegevens kunnen duidelijk twee groepen worden onderscheiden: Op de posities vóór de sluisdeuren (bemonsteringsposities 3, 6 en 9; rij A, Figuur 12) worden beduidend hogere aantallen glasalen gevangen dan op de overige 6 bemonsteringsposities (rijen B en C). Dit is een duidelijke indicatie dat er voor de sluisdeuren concentratie van glasalen plaatsvindt.

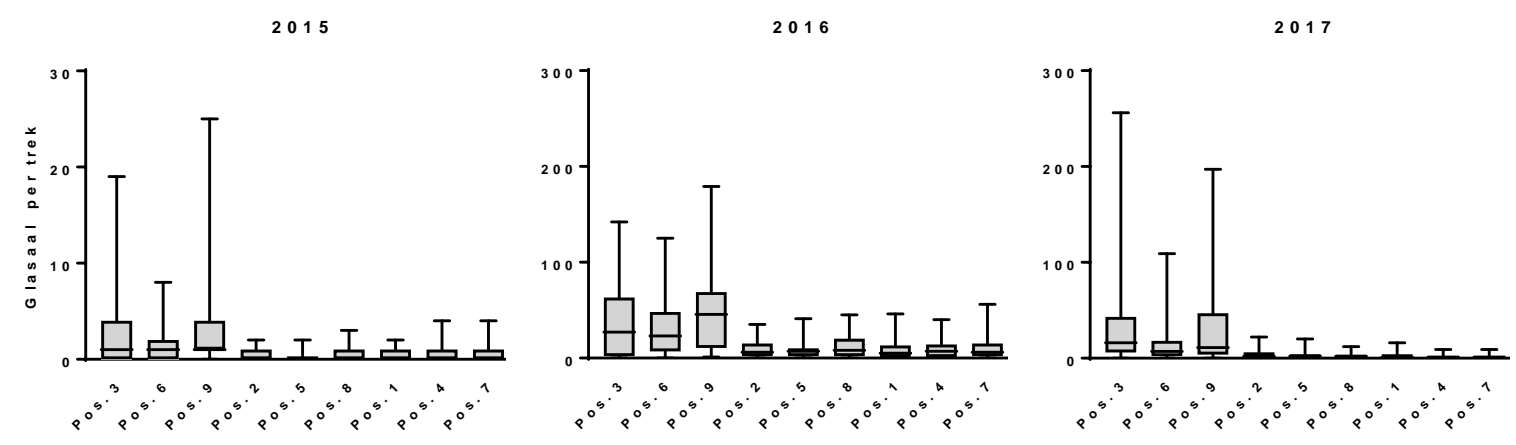

Figuur 12 Box-whisker plots van de aantallen gevangen glasaal per kruisnet trek op de 9 posities in de spuikom, gesorteerd op afstand van de sluis (posities 3,6,9 dichtbij, posities 1,4,7 verder weg, zie Figuur 6) weergegeven voor de jaren 2015, 2016 en 2017. Let op de verschillen tussen de Y-as van 2015 ten opzichte van de andere jaren. 


\subsubsection{Invloed van spuibeheer op glasaalverdeling}

Zoals in Figuur 12 aangegeven werden de hoogste dichtheden glasaal aangetroffen op de posities die zich het dichts bij de sluis bevinden (posities 3,6 en 9 op rij A), maar was er weinig verschil tussen de andere posities die verder van de sluis liggen ( $r i j$ B en $\mathrm{C}$ ).

Omdat de data van de 3 posities binnen één rij niet significant van elkaar bleken te verschillen zijn de subtotalen per rij gebruikt voor analyses om te onderzoeken of de verdeling van de glasalen in het onderzoeksgebied verandert onder invloed van het spuibeheer.

In Figuur 13 wordt de verdeling van de glasaalvangsten weergegeven op de 3 afstanden tot de sluis, rij $A$ dichtbij, rij $C$ het verst verwijderd, rij $B$ daar middenin. In het figuur wordt het relatieve aandeel van de locaties gepresenteerd, ten opzichte van de totale vangst tijdens de betreffende monitoringsronde waarbij alle 9 posities werden bemonsterd. De hoogte van het aandeel van rij $A$ in de totale vangst is een indicatie voor de mate waarin de in het gebied aanwezige glasalen zich ophopen voor de sluis.

\section{fractie glasaal gevangen bij verschillende afstanden}

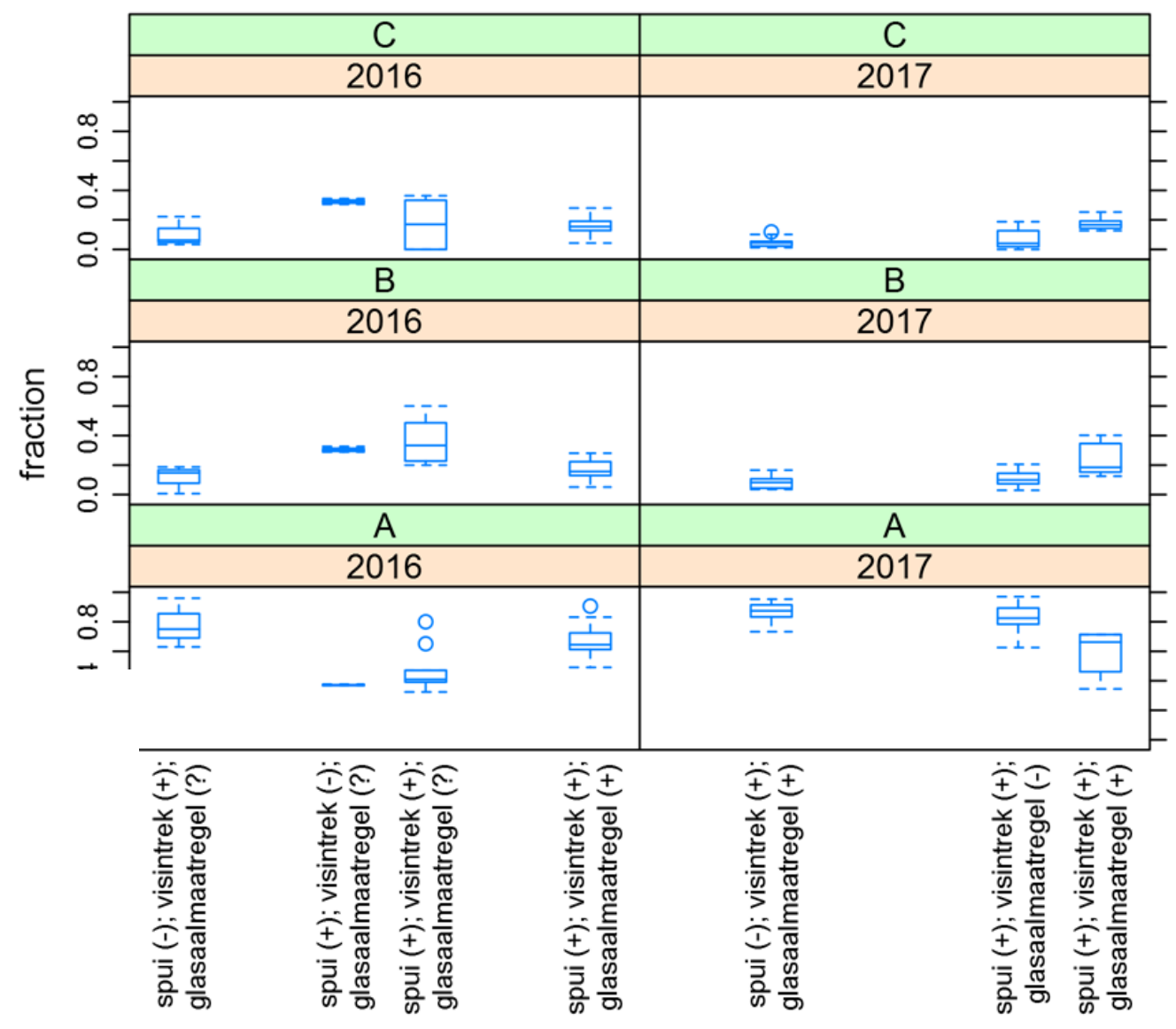

Figuur 13 Boxplots van de fractie van de totale hoeveelheid glasaal per monitoringsronde verdeeld over rijen $A$, B en $C$ met verschillende afstand tot het sluiscomplex ( $r i j A=$ posities 3, 6, 9; rij $B=$ posities 2, 5, 8; rij $C=$ posities 1, 4, 7). Gegevens van de jaren 2016 en 2017. Onder de figuur staan de omstandigheden voor het spuien weer gegeven.

De gegevens zijn gegroepeerd ( $\mathrm{x}$-as) op basis van wat bekend is over de spui/visintrekstand tijdens de terugvangst-bemonstering. Hieruit blijkt de grote onzekerheid rond het al dan niet in werking zijn van de glasaal-maatregel in 2016. Voor dat jaar is slechts 1 situatie waarbij gespuid en de visintrek en de glasaal-maatregel werd uitgevoerd met zekerheid vast te stellen. 
In 2017 was directe communicatie over de spui- en visintrekinstelling en konden 3 situaties met zekerheid gereconstrueerd worden. De glasaalvangsten in 2017 waarbij gespuid werd én de visintrekmaatregel werd uitgevoerd verschillen significant van elkaar afhankelijk van de glasaal-maatregel (wel of niet in werking). De fractie glasaal op rij A voor het sluizencomplex was groter toen de glasaalmaatregel niet werd uitgevoerd, en significant lager tijdens monitoring met de glasaal-maatregel in werking. Het is echter niet duidelijk of dit verschil verband houdt met de glasaal-maatregel op zichzelf. Immers, tijdens een andere bemonsteringsperiode in 2017 waarin de glasaalmaatregel ook doorgevoerd werd nog steeds een sterke ophoping van glasaal op rij A vastgesteld. Het enige verschil was dat er in die periode niet gespuid werd voorafgaand in de 24 uur voor de monitoring. De set van data met betrouwbare informatie over de spuistanden is te beperkt om de invloed van het spuibeheer op de verdeling van de glasalen hard te maken en te verklaren.

\subsubsection{Invloed van spuibeheer op de verblijftijd van glasaal}

Het uitzetten van gekleurde glasaal had als primair doel om inzicht te krijgen in de verblijftijd van de (gekleurde) glasalen in het onderzoeksgebied. In de spuikom konden in 2015 en 2016 echter onvoldoende glasalen worden verzameld om te kleuren waardoor er slechts sporadisch een gekleurd exemplaar werd teruggevangen (in 2015 geen, in 20162 gekleurde op de totaal 9532 glasalen).

Ondanks dat dit (theoretisch) ook een effect kan zijn van een korte verblijftijd wilden we uitsluiten dat het effect een resultaat was van een te kort aantal gekleurde glasaal. In 2017 werden daarom glasalen die waren verzameld in de schutkom uitgezet, waarvan er nu wel een aantal werden teruggevangen (50 gekleurde op de 5529 totaal). Het percentage teruggevangen gekleurde glasaal is per bemonsteringspositie uitgezet (Figuur 14), en vergeleken met de verdeling van de totale vangsten over deze posities (Figuur 14). Wanneer de gekleurde glasalen zich homogeen gemengd hebben met de niet gekleurde exemplaren is te verwachten dat het aandeel gemerkt en ongemerkt gelijk is tussen de verschillende posities. De homogene menging blijkt in de spuikom globaal het geval, met enkele bijzondere uitzonderingen. De gekleurde glasalen zijn oververtegenwoordigd op positie 3 en ondervertegenwoordigd op posities 9 en 6.

De oververtegenwoordiging op posities 3 ten opzichte van de ondervertegenwoordiging op posities 6 en 9 zou erop kunnen duiden dat de gekleurde glasalen een sterkere aantrekkingskracht voelden tot de westzijde van het sluizencomplex op rij A.

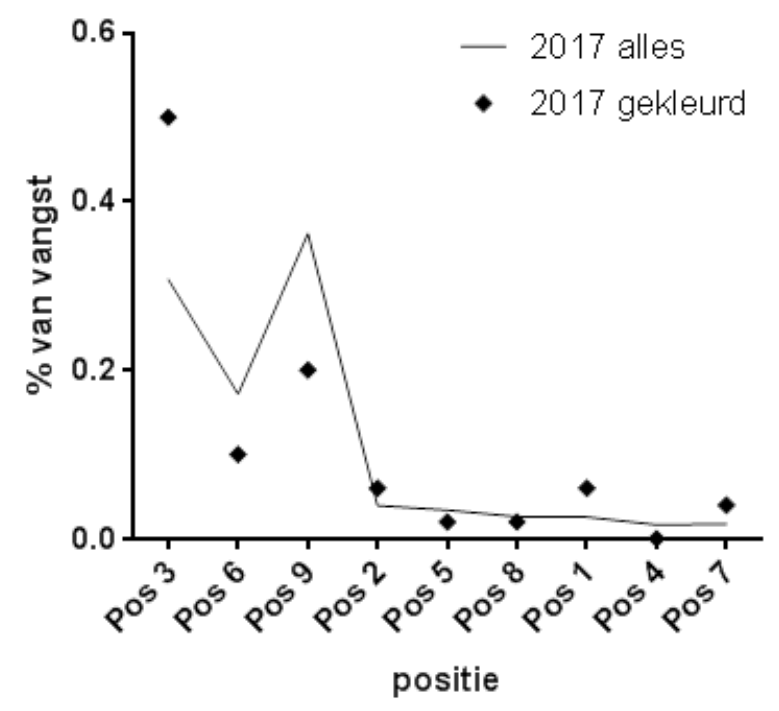

Figuur 14 Per positie in de spuikom zijn weergegeven de percentages van de totale glasaalvangst in 2017 (lijn), en de percentages van de totale hoeveelheid teruggevangen gekleurde glasalen (punten).

Wanneer de terugvangst van gekleurde glasalen als fractie van het aantal uitgezette exemplaren in de tijd wordt weergegeven kan bij voldoende terugvangst de verblijftijd in het onderzoeksgebied zichtbaar worden gemaakt. Zowel de terugvangst was echter zeer beperkt, en het aantal scenario's 
van spui/visintrek standen te groot en voor een deel onduidelijk waardoor er wordt geen logische relatie zichtbaar tussen de verblijftijd in het gebied en de maatregel kon worden bepaald. In de situaties waarin gespuid wordt lijkt de verblijftijd korter als de glasaalmaatregel in werking is (Figuur 15). Glasalen werden toen tot 5 dagen teruggevangen na uitzet, terwijl dit mèt de glasaal-maatregel tot 2 dagen is. Echter, wanneer de glasaalmaatregel in werking is terwijl er niet wordt gespuid is de invloed niet zichtbaar tijdens de monitoring.

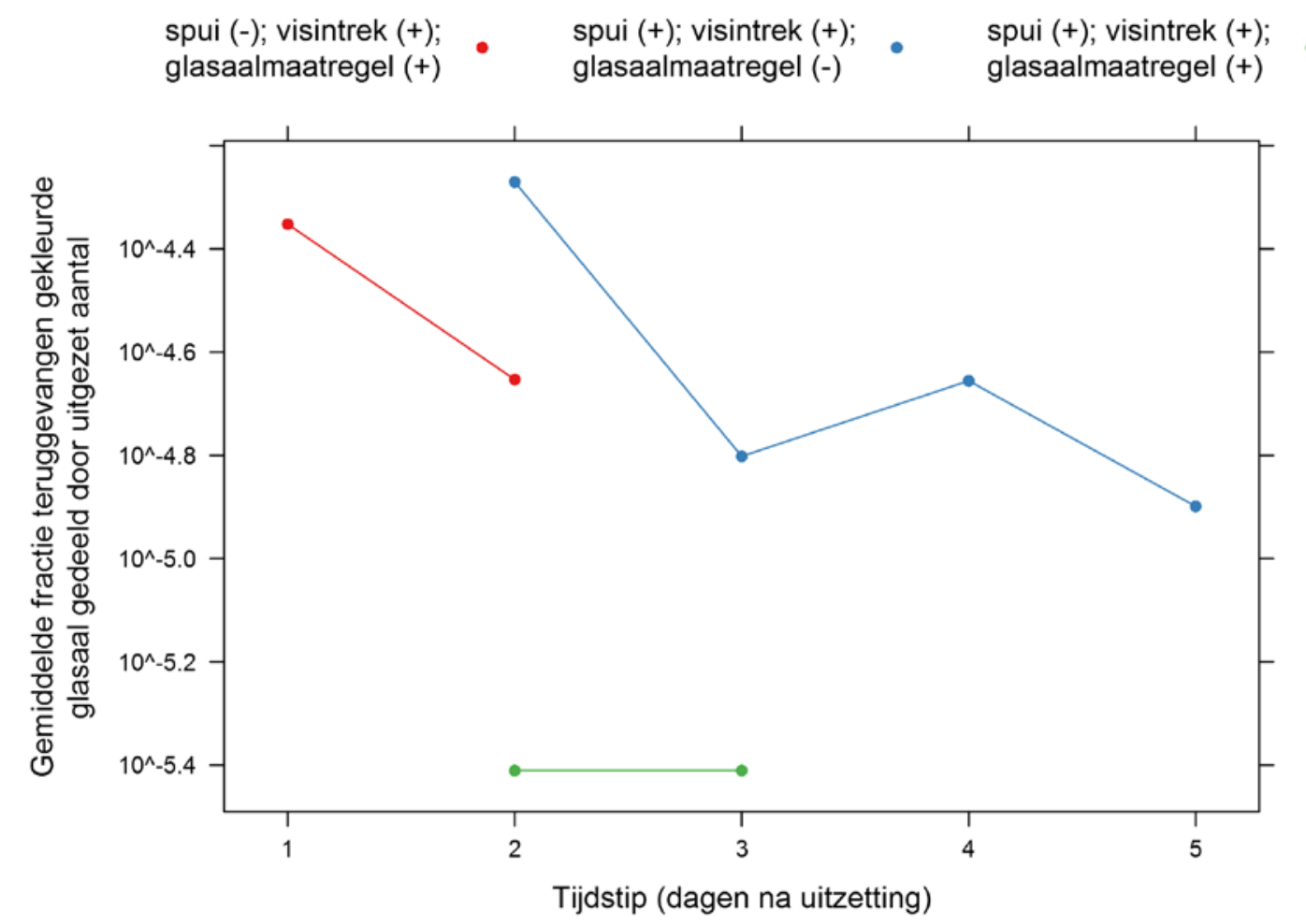

Figuur 15 Gemiddelde fractie terug gevangen gekleurde glasaal tijdens 3 verschillende merkterugvangexperimenten in 2017. Als er geen meetpunt in de figuur staat, betekend dat er die dag niet gemeten is. De hoeveelheid teruggevangen gekleurde aal is gebaseerd op 54 trekken per nacht. De hoeveelheid gekleurde aal varieerde van 0-27 stuks per trek.

\subsubsection{De relatie tussen de aantallen aanwezige glasalen en de glasaalindex}

Het aantal glasalen gevangen op rij A (posities 3,6 en 9) toont voor 2016 en 2017 een positieve correlatie met de vangsten van de index-vissers in dezelfde vangstperiode (Figuur 16). In 2015 is deze correlatie niet zichtbaar, waarschijnlijk als gevolg van de lage aantallen. De vangsten van de overige monsterposities (rijen $B$ en $C$ ) vertoonden geen correlatie met de vangsten van de index-vissers. In 2016 is de correlatie tussen rij A en de index-vissers steiler dan in 2017, in 2016 werden dus per, door de index vissers gevangen, trek meer glasaal gevangen in het gebied voor de sluizen ( $r i j A)$. 


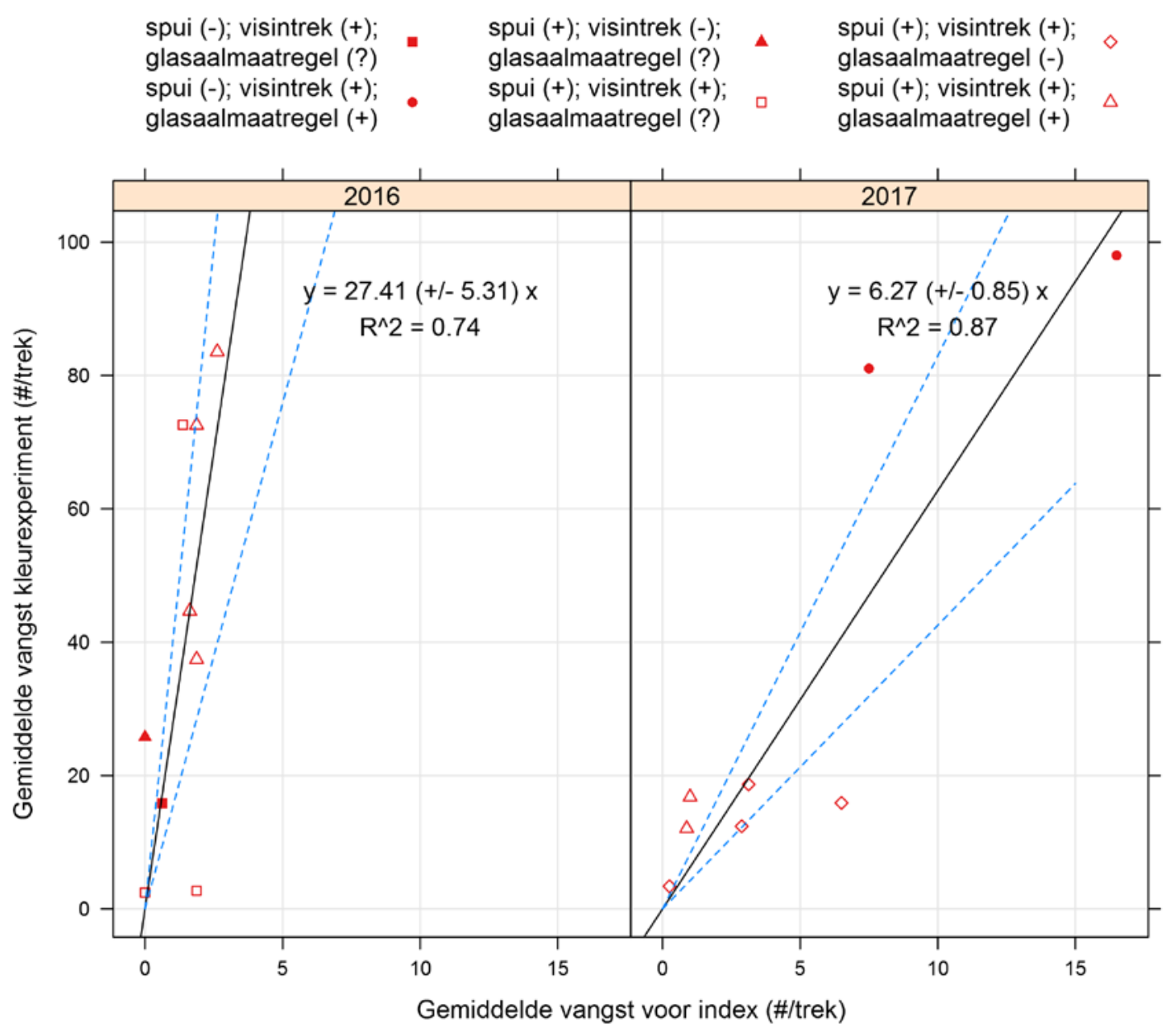

Figuur 16 Correlatie tussen de index-monitoring vangsten ( $1 \times 1 \mathrm{~m}$ ) en de kruisnetbemonsteringen (3x3m) op rij A op hetzelfde moment voor de jaren 2016 en 2017. De spui/visintrekstanden zijn met kleurcodes aangegeven

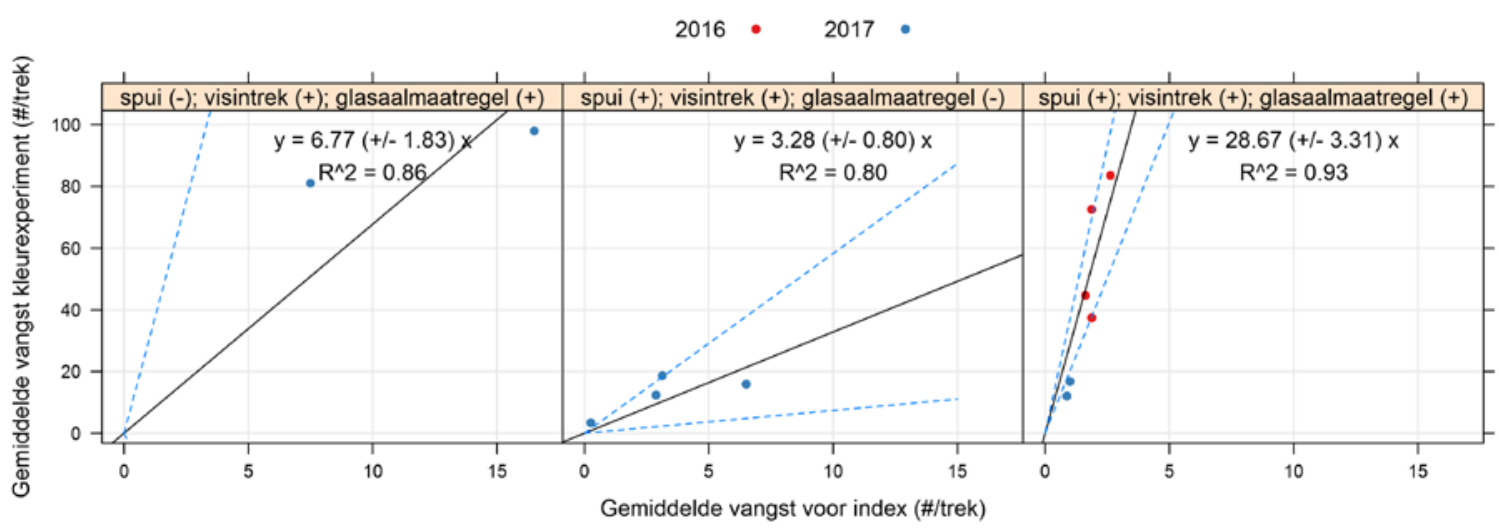

Figuur 17 Correlatie tussen de index-monitoring vangsten en de kruisnetbemonsteringen op rij $A$ op hetzelfde moment bij verschillend spuibeheer. Gegevens van 2016 en 2017

Om te onderzoeken of deze verschillen het gevolg kunnen zijn van verschillen in spuibeheer tussen die jaren is onderzocht of deze correlaties, onafhankelijk van het jaar, worden beïnvloed door het spuibeheer. Dit is alleen gedaan voor die bemonsteringsperiodes waarvan geen twijfel over de spui en visintrekstanden bestaat (Figuur 17). Hoewel de data beperkt is, suggereren de gegevens dat de relatie steiler wordt wanneer de glasaalmaatregel in werking is. Een logische verklaring zou kunnen zijn dat er minder ophoping van glasalen plaatsvindt in het gebied waar voor de index bemonsterd 
wordt, dus direct tegen de sluisdeur. Dit zou er dan op duiden dat binnen rij A ook van een concentratie gradiënt in de richting van de sluis sprake is, en dat deze minder sterk wordt wanneer de glasaal door de glasaalmaatregel een grotere kans krijgt richting het IJ sselmeer te zwemmen.

\subsection{Schutkom}

\subsubsection{Effecten van vismaatregelen op de verdeling van glasaal}

De hoeveelheden glasaal die werden gevangen tijdens de bemonsteringen in de schutkom waren in 2015 veel lager dan in 2016 (Figuur 18). In mei 2016 werden er bijvoorbeeld ruim 10 maal meer glasaal gevangen dan in dezelfde maand van 2015.

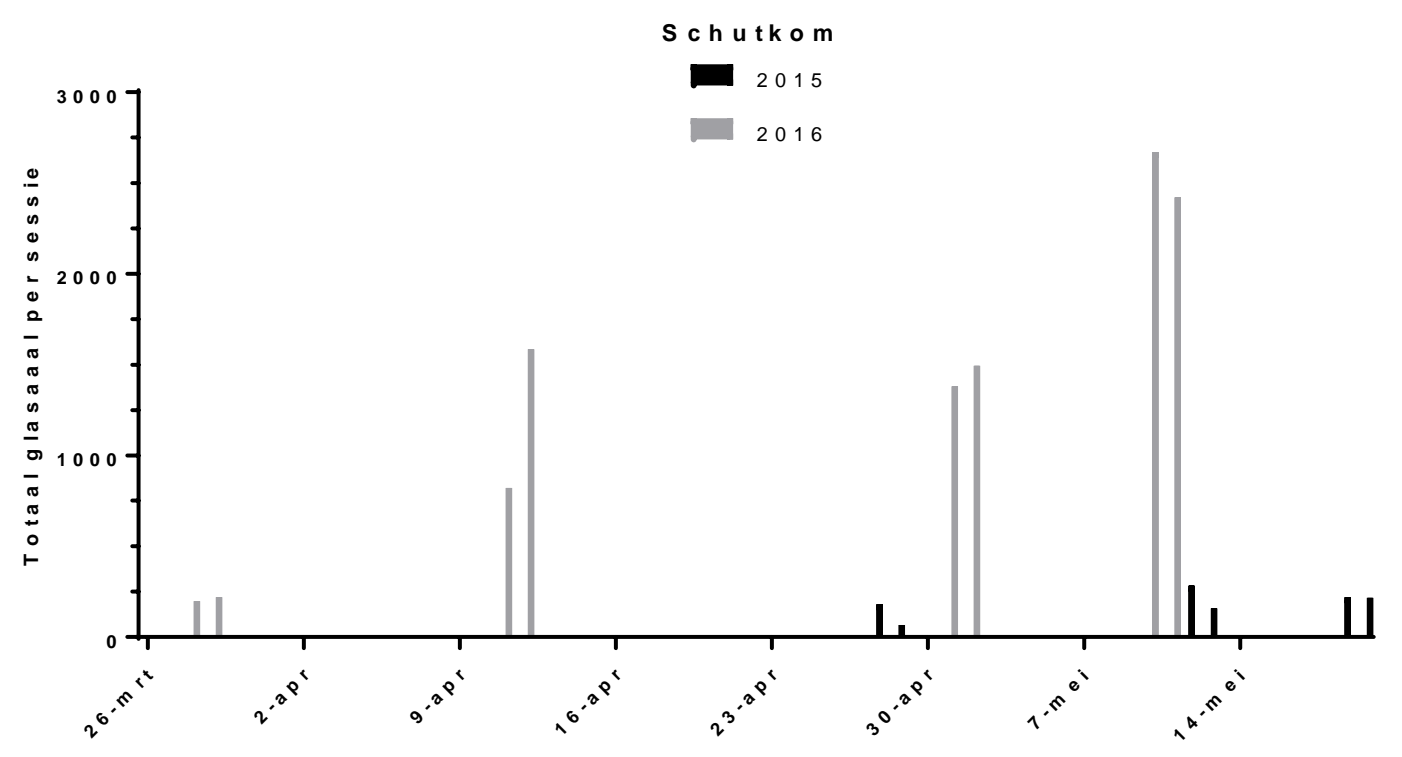

Figuur 18 Totaal aantal gevangen glasalen per monitoringssessie in de schutkom in 2015 en 2016

De glasalen waren niet in gelijke aantallen aanwezig op alle bemonsteringsposities in de schutkom. De vangstgegevens laten een duidelijke ophoping van glasaal zien rond positie 1 (Figuur 19) (nabij de plaats waar het RWZI-effluent en bemalings water wordt geloosd).

2015

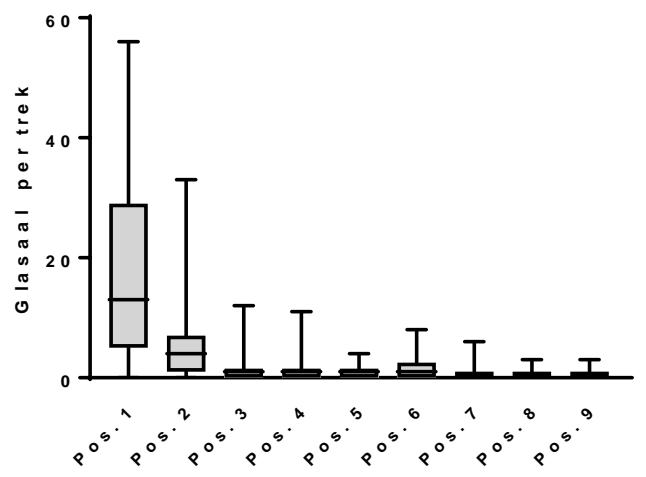

2016

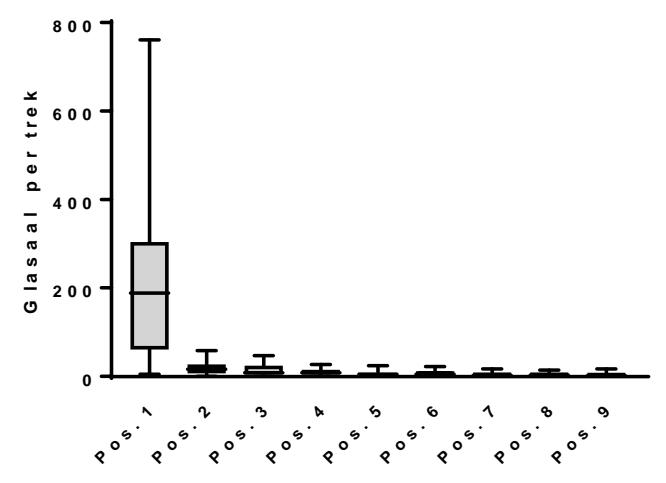

Figuur 19 Aantallen gevangen glasalen op de verschillende posities in de schutkom tijdens de bemonsteringssessies in 2015 en 2016

Met behulp van een clusteranalyse (niet weergegeven) is bepaald dat de dataset van 2015 (dus voordat vismigratie bevorderende maatregelen in werking waren), in 3 'clusters' verdeeld kan worden met duidelijke onderlinge verschillen. Veruit de meeste glasaal, rond $60 \%$ van de dagvangst, werd 
gevangen op positie 1, in de directe nabijheid van het RWZI-lozingspunt. Posities 2 en 3 vormen een middengroep en waren samen goed voor ca. 30\% van de totale vangst. Op de resterende posities 4 tot en met 9 was beduidend minder glasaal aanwezig. In totaal werd daar slechts ca $10 \%$ van het totale aantal gevangen.

In 2016, wanneer de vishevelpassage in werking is en extra schuttingen van de sluis worden uitgevoerd, worden de meeste glasalen nog steeds op positie 1 gevangen (Figuur 20). Het verschil tussen de clusters van posities 2 en 3, en van posities 4 t/m 9 is echter minder evident dan in 2015. Dit is vooral het gevolg van een lager aandeel van posities 2 en 3 . Ook is er veel meer spreiding in de glasaalvangst binnen de clusters. Zelfs bij de 'cluster' die slechts uit positie 1 bestaat. Dit betekent dat de glasaal zich waarschijnlijk meer in gaan verspreiden over het gebied, en dat de vangsten daardoor variabeler werden.

Op grond van deze gegevens kan worden aangenomen dat de glasalen in 2016 meer gelijkwaardig verdeeld waren over de schutkom dan in 2015, vooral doordat er op posities 2 en 3 minder ophoping van glasaal plaatsvindt. Dit zou goed het gevolg kunnen zijn van de hevelpassage nabij positie 2 , en de invloed van de extra schuttingen nabij positie 3. Door deze maatregelen zijn hier voor de glasalen mogelijkheden gecreëerd om naar het IJ sselmeer te trekken, waardoor op deze posities minder ophoping plaatsvindt. Deze maatregelen kunnen echter niet voorkomen dat er ook in 2016 nog een substantiële ophoping van glasaal bij het RWZI-lozingspunt aanwezig is.

\section{fractie glasaal gevangen op posities}

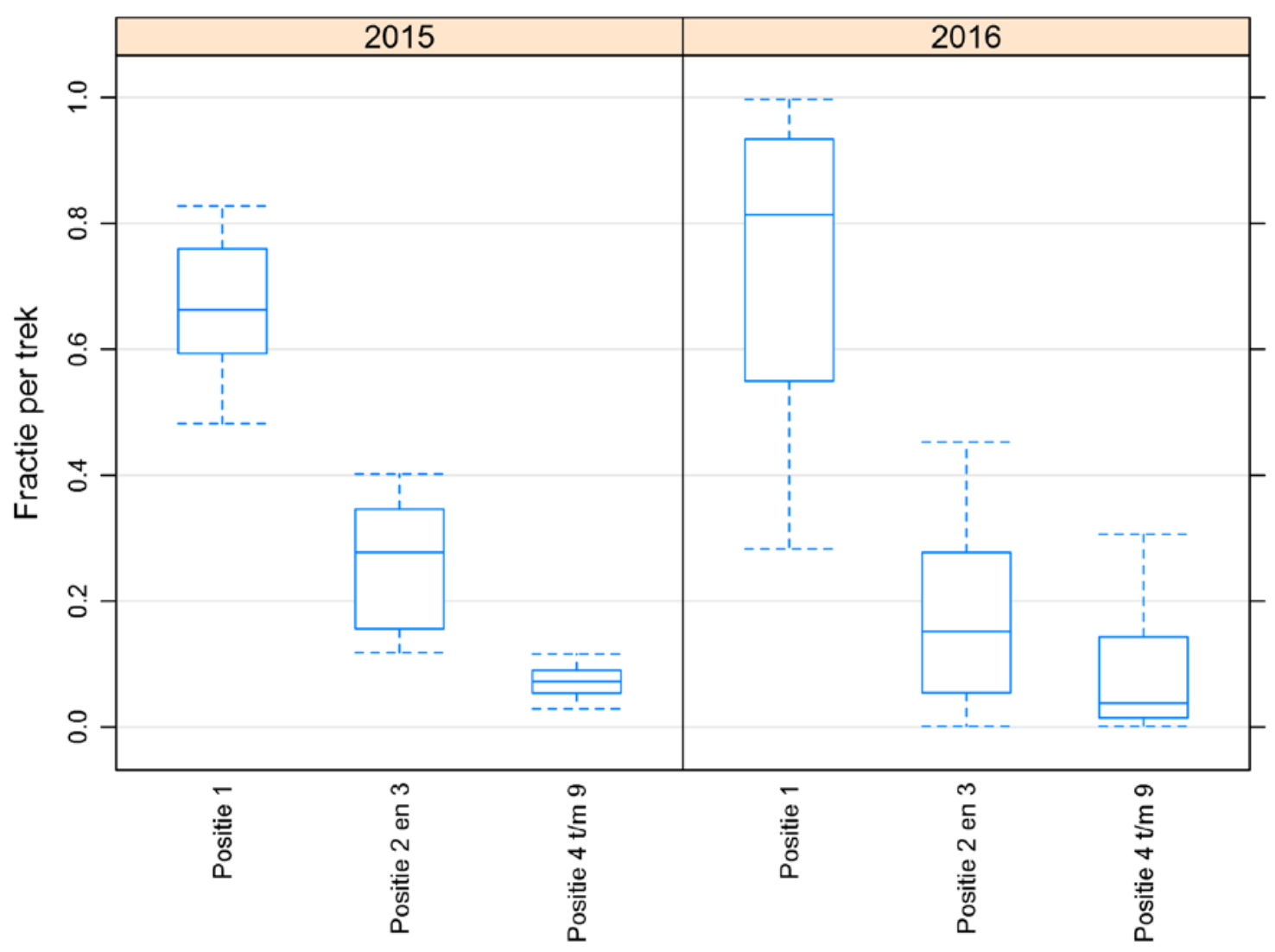

Figuur 20 Boxplots met daarin fractie van de gevangen glasaal (totaal) per trek in de schutkom op de verschillende posities (1), (2-3), (4-9). 


\subsubsection{Effecten van visintrekmaatregelen op de verblijftijd van glasaal}

Om een idee te krijgen van de verblijftijd van de glasalen in de schutkom zijn in 2015 en 2016 op verschillende momenten gekleurde glasalen uitgezet. Tijdens de daaropvolgende bemonsteringssessies bleek dat de verdeling van de gekleurde glasalen over de bemonsteringsposities gelijk te zijn aan de verdeling van de ongekleurde glasalen (Figuur 21). Hiermee is aangetoond dat de gekleurde glasalen zich gelijkmatig tussen de overige glasalen in het onderzoeksgebied hebben verdeeld.

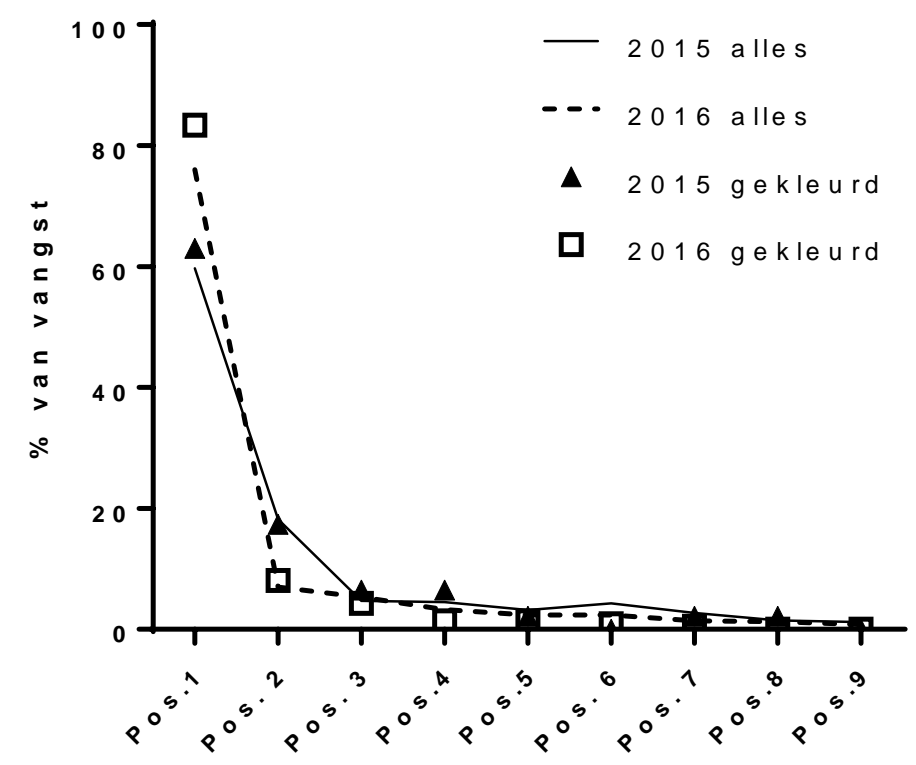

Figuur 21 Per positie in de schutkom de percentages van de totale glasaalvangst in 2015 en 2016 (lijnen), en de percentages van de totale hoeveelheid teruggevangen gekleurde glasalen (punten). Het vrijwel volledig samenvallen van de lijnen en punten geeft aan dat de gekleurde glasalen zich op dezelfde wijze over het gebied verdeelden als de ongekleurde.

Slechts een zeer klein deel van de in de schutkom uitgezette gekleurde glasalen werd teruggevangen. Op de eerste dag na de uitzetting was dit tussen 0.1 en $0.2 \%$ (Figuur 22). De daaropvolgende dag werd minder dan $0.1 \%$ van de uitgezette alen in de kruisnetten teruggevonden. De aantallen zijn zo laag dat het niet mogelijk is om op grond van deze gegevens verschillen in verblijftijden tussen de onderzoeksjaren aan te tonen. Omdat de terugvangst monitoring tot twee dagen na uitzetten van gekleurde aal plaatsvond, kan niet worden vastgesteld of de gekleurde aal langer dan 2 dag en in het gebied aanwezig was. 


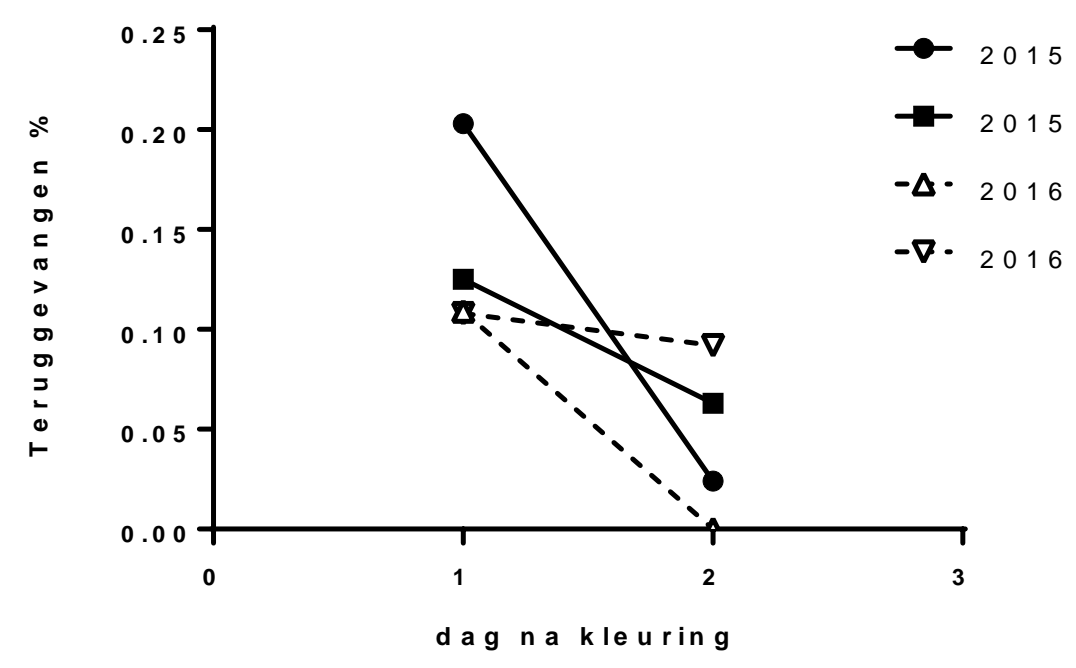

Figuur 22 Fractie gekleurde gevangen glasaal t.o.v. totaal gevangen glasaal in 4 periodes ( 2 merkterugvangexperimenten 2015, 2 merk-terugvangexperimenten 2016)

\subsubsection{Vishevelmonitoring}

In de periode van het WMR- terugvang onderzoek werd tevens onderzoek uitgevoerd naar de werking van de vishevelpassage in de schutkom. De hoeveelheid vis in de hevelpassage is gerapporteerd van 13 april tot en met 31 mei 2016.

In deze periode zijn 3 merk-terugvangexperimenten uitgevoerd, waarbij zowel in de schutkom als in de spuikom gekleurde glasaal is uitgezet. Tijdens monitoring in de hevelpassage zijn vrijwel dagelijks de aantallen glasaal, en het aantal gekleurde genoteerd. Dagelijks wisten tussen de 3000 en 55000 glasalen de weg naar de hevelpassage te vinden (Tabel 8).

Twee dagen voor de start van de monitoring in de hevelpassage op 13 april 2016, zijn in de schutkom 23000 gekleurde glasalen uitgezet. Bij aanvang van de monitoring, dus twee dagen na het uitzetten worden tussen 35000 glasalen 2 gekleurde exemplaren geteld in de passage. Drie dagen later wordt in de vishevelpassage een piek van gekleurde glasaal teruggevonden, met een totaal van 166 stuks (op 53600 totaal), op de twee volgende dagen slechts 2. Vijf dagen na het uitzetten van glasaal wordt er in de hevel passage geen gekleurde aal meer aangetroffen.

Op 10 mei 2016 wordt weer een partij gekleurde glasaal in de schutkom losgelaten. Ditmaal ca 19.500 stuks. De volgende twee dagen worden respectievelijk 36 en 18 gekleurde exemplaren in de hevelpassage aangetroffen tussen ruim 40.000 ongekleurde glasalen. Daarna worden geen gekleurde glasalen meer in de hevel aangetroffen. Deze waarnemingen uit de vishevelpassage suggereren dat de gekleurde glasalen in 2016 niet langer dan enkele (2-4) dagen in de schutkom verbleven, maar het kan niet worden uitgesloten dat het langer kan zijn.

Op de dagen dat er gekleurde glasalen in de hevelpassage werden aangetroffen lag de fractie gekleurde ten opzichte van ongekleurde alen tussen 0.0001 en 0.0031 . Dit is ruim 30 maal lager dan de fractie die in de kruisnetmonsters werd vastgesteld. De reden van dit verschil is onduidelijk, en kan een aanwijzing zijn van een lagere activiteit van de gekleurde alen. De vishevelpassage moet immers door de dieren actief worden benaderd en ingezwommen, terwijl met een kruisnet bemonstering ook minder actieve dieren worden gevangen. 
Tabel 8 Aantallen (gekleurde) glasaal gevangen in de monitoring bij de vishevel ten tijde van een aantal merk-terugvangexperimenten.

\begin{tabular}{|l|c|c|l|}
\hline datum & totaal in hevel & Waarvan gekleurd & Merk-terugvangexperiment \\
\hline $13 / 4$ & 34982 & 2 & Op 11 april in Schutkom 23000 glasaal uitgezet \\
$14 / 4$ & 53626 & 166 & \\
$15 / 4$ & 13202 & 2 & \\
$16 / 4$ & 33332 & 2 & Op 1 mei in Spuikom glasaal 1200 uitgezet \\
\hline $1 / 5$ & 22440 & 0 & \\
$2 / 5$ & 23760 & 0 & \\
$3 / 5$ & 20460 & 0 & \\
$4 / 5$ & 8581 & 1 & \\
$5 / 5$ & 20131 & 1 & \\
$6 / 5$ & 25746 & 6 & \\
$7 / 5$ & 15841 & 1 & \\
$8 / 5$ & 21126 & 6 & \\
$9 / 5$ & 32183 & 8 & \\
\hline $10 / 5$ & 41946 & 36 & \\
$11 / 5$ & 48528 & 18 & \\
$12 / 5$ & 23760 & 0 & \\
$13 / 5$ & 11880 & 0 & \\
$14 / 5$ & 3960 & 0 &
\end{tabular}

\subsection{Glasaal beweging tussen de kommen}

In 2016 is simultaan in de spuikom en schutkom gemonitord. Ook is er in de hevelpassage glasaal geteld, en zijn de aantallen gekleurde glasaal genoteerd. Op basis van de verzamelde gegevens kan worden onderzocht of de glasaal tussen beide gebieden heen en weer zwemt.

\subsubsection{Van Spuikom naar Schutkom}

In periode 28-31 maart 2016 werd in de spuikom voor de WMR monitoring 670 gekleurde glasaal uitgezet. In de schutkom wordt tijdens de WMR monitoring geen gekleurde aal aangetroffen (totaalvangst 527). De hevelpassage werd toen nog niet bemonsterd.

In periode 3 (1-3 mei), waarbij 1200 gekleurde glasalen in de spuikom zijn uitgezet, wordt in de schutkom geen gekleurde glasaal gevangen tijdens de MWR monitoring (totaal vangst 2873). In de vishevelpassage wordt na een aantal dagen echter wel gekleurde aal aangetroffen (Tabel 8). Na 3 en 6 dagen nadat gekleurde glasaal was in de spuikom uitgezet, wordt gekleurde aal aangetroffen in de hevelpassage. Ook de volgende dagen wordt nog gekleurde aal gevangen, maar hiervan kan een deel afkomstig zijn van een nieuwe uitzetting van gekleurde aal in de schutkom zelf. In elk geval is uit deze gegevens duidelijk dat er glasalen vanuit de spuikom naar de schutkom zwemmen of door wegspoeling middels het spuien opnieuw het complex benaderen en zodoende bij de schutkom uitkomen. Volgens deze redenatie is het onwaarschijnlijker dat glasaal van de schutkom naar de spuikom beweegt.

\subsubsection{Van schutkom naar spuikom}

In de spuikom wordt in periode 2 (waar dan géén gekleurde aal is uitgezet) op 14 april 1 gekleurde glasaal (op een totaal van 1868) teruggevangen. Het kan niet worden uitgesloten dat dit een glasaaltje is uit het merk-terugvangexperiment in periode 1 (28-31 maart) die in de spuikom is achtergebleven (670 gekleurde alen zijn in periode 1 uitgezet). Een andere mogelijkheid is dat dit 
glasaaltje van de schutkom naar de spuikom is gezwommen, maar dat lijkt onwaarschijnlijk vanwege de spuidruk. In periode 4 (12 mei) wordt geen gekleurde aal in de spuikom aangetroffen.

\subsection{Bestandsschattingen}

De onderzoeksgegevens zijn gebruikt om een schatting te maken van de hoeveelheden glasalen die in het onderzoeksgebied aanwezig waren. Dit is op twee manieren uitgevoerd; 1 ) op basis van de aantallen gevangen glasalen in de kruisnetten, 2) op basis van het aandeel gekleurde alen in de vangst.

Voor de eerste benadering is met behulp van Google Maps het oppervlak van het onderzoeksgebied geschat waarbij een opsplitsing is gemaakt naar de clusters van bemonsteringsposities (Tabel 9). Het bestand aan glasaal is vervolgens geschat door het oppervlakte van elk cluster te vermenigvuldigen met het gemiddelde aantal glasalen dat per kruisnet oppervlak op de in het cluster gelegen posities. De belangrijkste onzekerheidsfactoren in deze benadering betreffen de schatting van het oppervlak van de clusters en de representativiteit van de bemonsterde posities voor de gehele cluster.

Bij de tweede methode is de fractie van gekleurde glasalen in de totale dagvangst als uitgangspunt genomen. Het bestand is vervolgens geschat door het aantal uitgezette gekleurde glasalen te delen door deze fractie. De merk-en-terugvangmethode is een veel gebruikte methode om bestanden te schatten. Voor een zorgvuldige schatting is het van belang dat de gemerkte dieren zich random verspreiden onder de niet gemerkte, en dat er zich tussen het moment van merken en terugvangen geen wijzigingen voordoen in het aantal gekleurde en ongekleurde individuen. Dit laatste aspect was hier zeker niet aan de orde omdat er in principe van een constante aanvoer van nieuwe glasaal sprake was en er tegelijkertijd ook glasaal (al dan niet gekleurd) het onderzoeksgebied kon verlaten.

Tabel 9 De clustering van de onderzoeksgebieden en het geschatte oppervlakte zoals gebruikt bij de bestandsschattingen op basis van de kruisnet vangsten.

\begin{tabular}{|l|ll|ll|}
\hline & \multicolumn{2}{|l|}{ Spuikom } & \multicolumn{2}{l|}{ Schutkom } \\
\hline Cluster 1 & Posities 3,6,9 & $53333 \mathrm{~m}^{2}$ & Positie 1 & $3000 \mathrm{~m}^{2}$ \\
\hline Cluster 2 & Posities 2,5,8 & $53333 \mathrm{~m}^{2}$ & Positie 2,3 & $6000 \mathrm{~m}^{2}$ \\
\hline Cluster 3 & Posities $1,4,7$ & $53333 \mathrm{~m}^{2}$ & Positie $4-9$ & $36000 \mathrm{~m}^{2}$ \\
\hline & Totaal & $160000 \mathrm{~m}^{2}$ & Totaal & $45000 \mathrm{~m}^{2}$ \\
\hline
\end{tabular}

Op basis van deze gegevens blijkt dat op de bemonsteringsdagen van 2016 en 2017 rond de één miljoen glasalen in de spuikom verbleven. In 2015 lag dit getal een stuk lager met een maximum van net boven de 50.000 stuks. In de schutkom waren in dezelfde periode iets lagere aantallen glasaal aanwezig. Een schatting komt uit op rond de 200000 in 2016 en rond 100000 in 2015. Wat het aanbod buiten de bemonsteringsdagen is geweest, is onbekend.

Ondanks onzekerheden in de benadering resulteren beide methoden in een aanbodschatting die in dezelfde orde van grootte liggen (Figuur 23). Rond half april 2017 resulteren de spuikom gegevens in de grootste verschillen tussen de berekeningsmethoden, waarbij met het merk-en-

terugvangexperiment een substantieel hoger bestand wordt geschat. Dit zou het gevolg kunnen zijn van veranderingen in de aantallen (gekleurde) glasalen tussen het merken en terugvangen (óf meer aanwas van ongekleurde aal, óf dat dat er relatief meer gekleurde aal is weggetrokken). 

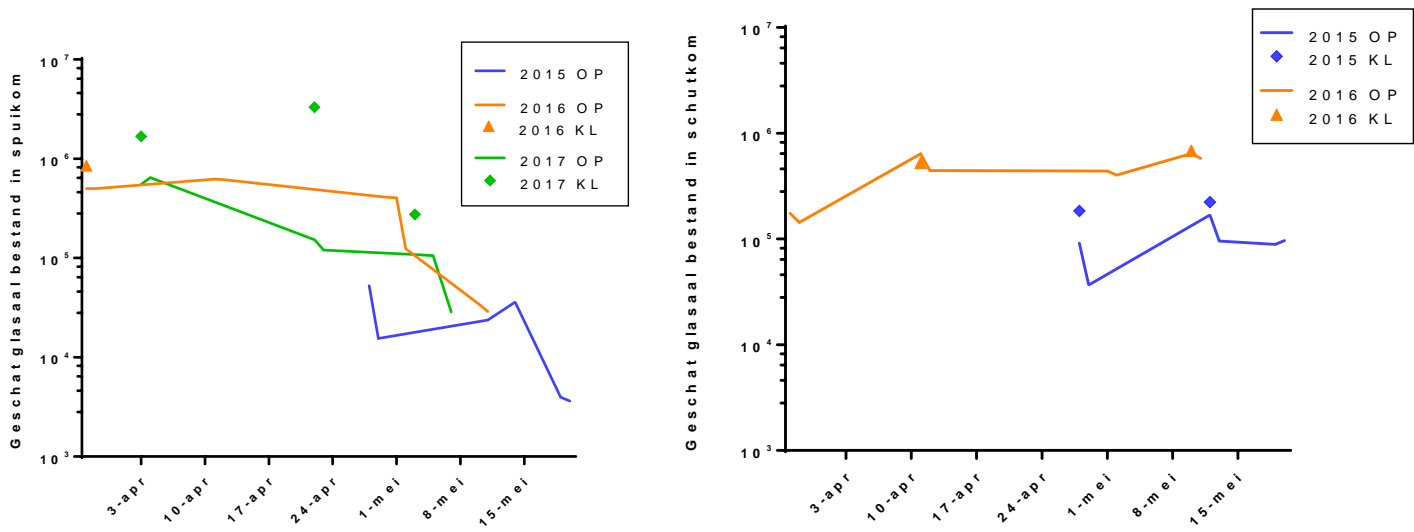

Figuur 23 Geschatte hoeveelheid glasaal in 2015, 2016 en 2017 berekend volgens 2 verschillende methoden. $\mathrm{OP}=$ op basis van oppervlakte, $\mathrm{KL}=$ op basis van de fractie gekleurde aal. 


\section{$6 \quad$ Discussie}

\subsection{Opzet onderzoek en beschikbare informatie}

\subsubsection{Onderzoeksmethoden}

Voor het in dit rapport beschreven onderzoek is gebruik gemaakt van kruisnetten met een oppervlak van $3 \times 3$ meter in de spuikom en $1.5 \times 1.5$ meter in de schutkom. Van de beschikbare netten waren dit de maximale maten die van de beide boten ingezet konden worden. Op beide locaties zijn in 2015 ook met een $1 \times 1$ net bemonsteringen uitgevoerd, maar daarmee werd beduidend minder glasaal gevangen. De vangstefficiëntie van deze kleinere netten was minder dan op basis van het verschil in oppervlak berekend zou worden, waarschijnlijk doordat bij een kleiner net een groter deel van de glasalen die zich in de waterkolom boven het net bevindt in staat is het net te ontwijken. Tijdens parallelle bemonsteringen met het $3 \times 3 \mathrm{~m}$ kruisnet en het $1 \times 1 \mathrm{~m}$ kruisnet in de schutkom in 2015 werd zo vaak geen glasaal gevangen op het kleine net dat er geen correlatie tussen beide netten kon worden bepaald. Naast het eerdergenoemde verschil in vermijdingssucces, wordt het vangsucces tevens hoogstwaarschijnlijk beïnvloed door de ophaalsnelheid, en de stroomsnelheid van het water en de daarmee samenhangende positie van het net $(1 \times 1$ net heeft eerder de neiging mee te hangen op de stroming dan het $3 \times 3$ net, waardoor de vangsten beïnvloed kunnen raken). In stromend water zal met een lichter net immers geen verticale maar een diagonale waterkolom worden bemonsterd. Om de vangsten te maximaliseren is voor de bemonstering gebruik gemaakt van de grootste netten die inzetbaar waren. Het was daardoor niet mogelijk de vangsten één op één te vergelijken met de monitoring ten bate van de glasaalindex die met een $1 \times 1 \mathrm{~m}$ net worden uitgevoerd.

In 2004 stellen Dekker et al vast dat "bij een statistische verwachting van 100 glasalen per trek bedraagt de trek-tot-trek variatie ca. 65; bij een gemiddelde van 100 glasalen per trek wordt in $15 \%$ van de gevallen meer dan 165 glasalen gevangen, en in $15 \%$ minder dan 35. Bij lagere dichtheden neemt deze variatie weliswaar in absolute aantallen af, maar procentueel gezien is er sprake van een toename! Hoe geringer de vangsten, des te lager de betrouwbaarheid." Dit effect is duidelijk zichtbaar in de huidige vangstgegevens. Doordat er de laatste jaren nog maar lage aantallen glasaal worden gevangen in de monitoring is de variatie tussen de vangsten erg hoog. Gemiddeld werden in 2015 t/m 2017 tussen 0.4 en 2 glasalen per trek gevangen met het 1x1m net. De standaard deviatie lag twee maal hoger dan dit gemiddelde (Tabel 7).

Dit geeft aan dat de betrouwbaarheid van de huidige lage glasaal-index getallen laag is. Hierdoor is het op basis van het onderzoek in de afgelopen jaren feitelijk niet mogelijk om verschillen in de glasaalindex vangsten tussen jaren, of perioden binnen een jaar statistisch hard te maken. Langjariger informatie en langjarige trend analyses zijn nodig om conclusies te kunnen trekken over het verloop van glasaal, glasaalherstel en eventuele trendbreuk.

Ondanks deze wetenschap is in dit rapport toch getracht een relatie te leggen tussen de glasaalindex vangsten en de vismigratie bevorderende maatregelen. De uitkomsten van deze analyses kunnen echter hooguit als indicatief worden beschouwd.

De lage dichtheid aan glasaal had ook invloed op de resultaten van de merk-terugvangexperimenten. Vooral in de spuikom konden niet voldoende glasalen worden gevangen om een betrouwbaar merken-terugvangexperiment mogelijk te maken. In 2015 waren de vangsten in de spuikom zo laag dat daar geen merk-terugvangexperiment werd uitgevoerd. In 2016 waren de vangsten hoger, en zijn wel gekeurde exemplaren uitgezet, eerst rond 700 exemplaren en in een tweede ronde rond 1200. Deze aantallen waren te waarschijnlijk laag voor deze locatie, want hiervan werd in totaal slecht 1 exemplaar teruggevangen. Ondanks dat de lage terugvangst ook gelegen kan zijn in een lage verblijftijd van glasaal, is voor opvolgende monitoring gekozen om substantieel grotere aantallen gekleurde aal uit te zetten. In 2017 konden hogere aantallen gekleurde glasaal worden uitgezet door hiervoor glasaal te verzamelen rond de RWZI-uitlaat in de schutkom. Van 3 uitzettingen van in totaal 
ca 37000 gekleurde glasalen werd tussen 0.02 en $0.14 \%$ in het $3 \times 3 \mathrm{~m}$ kruisnet teruggevangen. Globaal werd per bemonsteringssessie ( 6 meetrondes langs de 9 posities) $0.3 \%$ van het oppervlak van de spuikom bemonsterd (Tabel 9).

De teruggevangen aantallen ongekleurde en gekleurde glasalen zijn waarschijnlijk te laag om duidelijke conclusies aan te kunnen verbinden over verblijftijden. Voor meer betrouwbare metingen zullen meer gekleurde glasalen moeten worden uitgezet of - bij voorkeur - een groter oppervlak worden bemonsterd. Beide opties kennen echter praktische beperkingen. Een uitgebreidere bemonstering is nauwelijks mogelijk omdat de bemonstering binnen een beperkt tijdsframe uitgevoerd moet worden. Het verzamelen van meer glasaal voor de kleuring is alleen mogelijk wanneer deze glasalen op een andere locatie gevangen worden, zoals in 2017 het geval was met glasaal uit de schutkom. Hier reist dan echter de vraag of deze glasalen representatief zijn voor de alen die 'van nature' in het onderzoeksgebied aanwezig zijn. De verdeling van de in 2017 in de spuikom uitgezette gekleurde 'schutkom-alen' leek toch enigszins af te wijken van de verdeling van de echte 'spuikom' alen. Terwijl gekleurde 'schutkom-alen' zich wel gelijkmatig over hun soortgenoten lijken te verdelen als zijn in de eigen schutkom worden teruggezet. Dit lijkt een aanwijzing om voorzichtig om te gaan met het gebruik van gemerkte dieren die uit een ander gebied afkomstig zijn.

\subsubsection{Co-variabelen in de glasaalvangst}

Het onderzoek had betrekking op het vinden van relatie tussen de glasaalvangsten in zowel de indexmonitoring als de kruisnetvangsten in de merk-en terugvangsexperimenten waarop de maatregelen op het sluizen en spuicomplex een effect konden hebben. Glasaalaanwezigheid in zowel de spuikom als de schutkom wordt echter niet alleen bepaald door de maatregelen aan het spui en sluizencomplex bij Den Oever. Een aantal natuurlijke variabelen heeft direct of indirect effect op de hoeveelheid glasaal op het moment van de monitoring. Een aantal bekende variabelen zijn; verschillen tussen seizoenen (aantal glasaal, moment dat de intrek start, temperatuurverloop gedurende het seizoen), getijde invloed, en de biologische relatie tussen omgeving en glasaal(gedrag).

De effecten en mate van invloed van deze co-variabelen op de vangsten is niet bepaald in dit onderzoek. Het effect van het getij zal deels samenvallen met het effect van spuien, omdat spuien sterk gekoppeld is aan de waterstanden. Het effect van het getij op de vangsten binnen een meetronde veronderstellen we als gering omdat een meetronde over alle meetlocaties ongeveer een half uur duurt, en veelal niet op de kentering plaatsvond (wanneer het getij effect het grootst is). De effecten van de omgeving op het gedrag van glasaal zoals wind, saliniteit en temperatuur zullen een rol spelen in waar de glasaal zich ophoudt en verdeeld is in het gebied. Nabij de bodem (wind), of sneller zwemt (temperatuur). Deze variabelen hebben we niet getest in het onderzoek en zijn aandachtspunten voor opvolgend glasaal onderzoek dat zich richt op verdeling en verblijftijden. Een markante waarneming is de oververtegenwoordiging van gekleurde glasaal aan de westzijde van de spuikom (in 2017- zie Figuur 14). Een veronderstelling bij deze waarneming is dat de gekleurde glasaal- die afkomstig is uit de schutkom- meer affiniteit heeft met de westzijde van de spuikom omdat dit dichterbij de schutkom gepositioneerd is. Een relatie met saliniteit op de vangsten en op de locaties is niet geanalyseerd, en wellicht zijn er ook andere - nog onbekende- invloeden bepalend voor deze waarneming.

\subsubsection{Merk en terugvangst experimenten}

Merk en terugvangst experimenten zijn nuttige onderzoekstechnieken om indicatie te krijgen over het aanbod en de verblijftijd van in dit geval glasaal in het studiegebied. Omdat het een onderzoeksgebied in open verbinding staat met zowel zee, als gedeeltelijk met het binnenwater is er dus zowel aanwas van glasaal uit zee, als doortrek van glasaal naar het binnenwater. Beide hebben invloed op de hoeveelheid aal in het gebied, en is onderhevig aan dagelijkse zwembeweging en migratie van de dieren. Een exacte bestandsbepaling is dan ook niet mogelijk, maar een redelijke schatting van het aanbod op het moment van de monitoring, aangenomen dat de aanwas en doortrek gelijk zouden zijn is in dit rapport geschetst.

Met deze methode is ook inzicht verkregen in de migratie van glasaal van de spui- naar de schutkom. De aanname ten tijde van aanvang van het onderzoek - op basis van eerdere ervaringen- was dat de aangebrachte kleuring tot ongeveer een week zichtbaar zou zijn. Dit gegeven maakte dat het merk-en 
terugvang experiment dat wisselend in de spuikomen schutkom werd uitgevoerd in 2016, géén verwarring zou opleveren waar de gekleurde glasaal vandaan zou komen. Echter blijkt in de vishevelmonitoring dat er na ruim een week alsnog gekleurde glasaal wordt aangetroffen die alleen maar afkomstig ka zijn uit de spuikom. Ervaringen in andere recente onderzoeken geeft tevens aan dat de kleuring langer zichtbaar kan blijven dan een week (pers. communicatie B. Griffioen). In dit onderzoek heeft de langere kleuring geleid tot inzicht dat glasaal van de spui naar de schutkom zwemt. In opvolgende experimenten zal moeten worden bepaald of dergelijke kleuring voor het type onderzoek wenselijk is of niet.

\subsubsection{Informatie over spui en visintrekstanden}

De instellingen van visvriendelijke beheermaatregelen- zowel in spuikom als in de schutkom- bleken pas laat in de uitvoering van het project onvoldoende vastgelegd bij de uitvoerende instanties. Reden van het onderzoek, en daarmee bepalend voor de werkplannen in dit onderzoek, was het spuibeheer en de effecten van specifiek de visvriendelijke maatregelen op de index vangsten. De verandering van het beheer ná 2015 was aanleiding om het onderzoek uit te voeren. Echter, in de praktijk is gebleken dat de omstandigheden niet altijd goed werden gecommuniceerd en of genoteerd. Dit heeft grote impact op de analyse en de kracht van de conclusies teweeggebracht.

Aanvankelijk zou 2015 gelden als T0 situatie- waarbij geen van de aanvullende visvriendelijke maatregelen in werking zou zijn getreden. Begin 2016 zouden de maatregelen worden ingesteld, en 2017 zou gelden als T1- om een effect van de maatregel vast te stellen. Eind 2015 werd gecommuniceerd dat de visvriendelijke maatregelen in de spuikom vertraging opliepen, en pas na 2016 in werking zouden treden, waarop de werkplannen voor 2016 en 2017 zijn aangepast. Omdat de vangsten in 2015 erg laag waren, en de T0 beschrijving daarmee beperkte zeggingskracht hadden, werd de monitoring van 2016 als een tweede T0 meting herplant. De metingen van 2017 zouden vervolgens gelden als een $\mathrm{T} 1$.

In april 2017 bleek dat de maatregelen wel degelijk per december 2015 in werking waren getreden. De uitgangspunten van het werk dat was uitgevoerd in 2016 bleken niet meer van toepassing. Met terugwerkende kracht is geprobeerd de reeds verzamelde data te rubriceren naar bruikbare informatie. Bij deze poging kwam een aanvullende onduidelijkheid aan het licht: niet alleen was de maatregel eerder in werking gesteld, maar deze bleek per 26 april 2016 ook weer te zijn teruggedraaid. Het terugdraaien van de maatregel bleek ook in 2017 nog van kracht vanwege veiligheidsaspecten. Deze beperking voor het inwerkingstellen van de glasaalmaatregel bestond echter alleen voor ingehuurde sluisbedieners. Met andere woorden: de glasaalmaatregel werd wél in werking gesteld als er een vaste bedienaar dienst had, en werd níet in werking gesteld als er een inhuur kracht dienst had. Voor de periode 26 april 2016 tot en met eind mei 2017 zijn de glasaal-vriendelijke maatregelen nabij de spuisluizen dus wisselend in werking gesteld, afhankelijk van het dienstrooster. Een poging het dienstrooster te koppelen aan onze dataset is daarom niet gelukt.

Sinds de melding over de voortdurende onduidelijkheid met betrekking tot de glasaalmaatregel is voor de resterende periode in 2017 nauw overleg gevoerd over de periodes waarin de merk-

terugvangexperimenten plaatsvonden, en de instellingen van de visvriendelijke maatregelen. Voor de 3 monitoringsperiodes in 2017 zijn complete instellingscombinaties beschikbaar.

Voor de voorgaande periodes heeft geen nauw overleg plaatsgevonden omdat de instellingen zouden zijn opgeslagen in het zgn. "journaal" dat ons ter inzage zou worden gesteld. Echter bleek in de loop van 2017 bij het naslaan van deze informatie dat de informatie beperkt was ingevoerd. Op een enkele invoer na, is er geen informatie vastgelegd over de glasaalmaatregel, of het aantal schuttingen. 


\section{$7 \quad$ Conclusies}

\subsection{Samenvattend}

De aanleiding van dit onderzoek is de inwerkingtreding van diverse visvriendelijke maatregelen bij Den Oever, en de aanname dat dit effecten kan hebben op de glasaalindex.

De vraag bij dit onderzoek was, of de aanwijzingen voor effecten op de glasaalindex-waarde hard genoeg gemaakt kunnen worden. Als dit niet zo is, dan zijn er twee mogelijke verklaringen. Of de effecten van de maatregelen zijn er niet, óf het onderzoek laat dit niet zien. Als effecten worden aangetoond, dan is het vervolgens aan de orde om te bepalen of de mate van de effecten ook te kwantificeren zijn. Als de effecten niet zijn aan te tonen, of niet te kwantificeren, dan kan de eventuele correctie op de index ook niet worden bepaald. In dit onderzoek zijn er indicaties dat de maatregelen effect hebben op de glasaalverdeling in het gebied, en dus mogelijk een effect kunnen hebben op de vangsten van de glasaalindex-monitoring. Heel hard zijn deze aanwijzingen in dit onderzoek echter niet. Een reden kan zijn dat dit ligt in lage datadichtheid vanwege de ontbrekende informatie en lage glasaalvangsten. Op basis van dit onderzoek kunnen we niet uitsluiten noch hard maken dat er effecten van de maatregelen op de glasaalindex-vangsten, en dus de indexwaarde, zijn.

Om de voorzichtige bevindingen in dit onderzoek nader te onderzoeken kan een aanvulling op het onderzoek worden gedaan. Hierbij stellen wij een data-analyse van de indexdata over een meerjarige periode voor, en deze te koppelen aan de klepstanden en debiet gegevens van het sluiscomplex (in plaats van de logboekgegevens). Om over te gaan op een dergelijke exercitie is het eerst nodig om met de betrokken instanties verder te bespreken wat deze informatie exact kan betekenen irt spui, vis-spui en glasaalintrek, en hoe de vertaling te maken is naar de eventuele aanvullende data analyse. Hierbij is het ook relevant te achterhalen tot hoe ver terug in de tijd deze gegevens voorhanden zijn. Daarna kan bepaald worden of een dergelijke analyse van toegevoegde waarde is op onderliggende analyse.

\subsection{Effecten van de glasaalmaatregel op glasaal in de spuikom}

Doordat er geen zekerheid bestond over de spuistanden in 2015 en 2016, maar wel duidelijk was dat er van een nul-situatie geen sprake was, was het niet mogelijk om de resultaten per jaar met elkaar te vergelijken zoals oorspronkelijk de bedoeling was. In een laatste poging toch inzicht te krijgen in de invloed van het spuibeheer is het spuibeheer voor de onderzoeksperioden in 2017 in overleg met de sluisbeheerder voor het onderzoek aangepast. Samen met de eerder genoemde restricties beperkte dit de kracht van het onderzoek in de spuikom waardoor de resultaten meer indicatief dan concluderend zijn.

Het onderzoek in de spuikom had als doel inzicht te krijgen in de invloed van de vismigratiebevorderende maatregelen. Hierbij werden drie hypotheses opgesteld:

Hypothese 1) De glasaalindex vangsten correleren in alle jaren met de dichtheden glasaal vlak voor de sluisdeuren.

Dit blijkt het geval te zijn voor de jaren 2016 en 2017. In 2015 waren de vangsten te laag om zo'n correlatie zichtbaar te maken. In 2016 is de correlatie steiler dan in 2017, wat betekent dat er in 2016 meer glasalen voor de sluizen aanwezig waren bij dezelfde glasaal-index vangst. Omdat de spuistanden in 2016 voor een belangrijk deel onzeker zijn is de reden van het verschil tussen 2016 en 2017 niet vast te stellen. Een analyse van de gegevens waarbij het spuibeheer wel duidelijk is, suggereert dat de helling steiler is wanneer de glasaalmaatregel wordt toegepast. Dit zou betekenen dat er in dat geval minder glasaal ophoopt vlak voor de sluisdeur waar de bemonstering ten bate van 
de glasaalindex plaatsvindt. Als dit inderdaad het geval zou zijn, dan is de mogelijke consequenties dat er tijdens de index monitoring ook minder glasaal gevangen wordt, en daardoor de index waarde lager uitvalt. Echter, de onderzoeksresultaten bevatten veel onzekerheden om duidelijke uitspraak te kunnen doen in welke mate de glasaalindex zal worden beïnvloed door het instellen van de glasaalmaatregelen.

Hypothese 2) Door de maatregelen vindt er in de jaren 2016 en 2017 minder ophoping van glasaal voor de sluisdeuren plaats dan in 2015. De glasalen zijn dus meer gelijkmatig verspreid over het onderzoeksgebied.

De invloed van de maatregelen konden niet worden onderzocht door vergelijking van verschillende onderzoeksjaren. Er zijn geen aanwijzingen gevonden voor een substantiële verandering van de verdeling van de glasalen in de spuikom wanneer de glasaalmaatregel in werking is. Onder alle omstandigheden worden de meeste glasalen nog steeds in de rij het dichts bij het spuicomplex gevangen. Wel zijn er zoals bij hypothese 1 aangeven, aanwijzingen voor subtiele veranderingen in de verdeling van de glasalen vlak voor de sluizen

Hypothese 3) Door de maatregelen is de verblijftijd van (gekleurde) glasalen in het onderzoeksgebied korter in 2016 en 2017 dan in 2015

Op basis van de resultaten van de uitgevoerde experimenten kan geen uitspraak worden gedaan over de verblijftijd van de glasalen in de spuikom en of de maatregelen daarop van invloed zijn.

\subsection{Effecten van maatregelen op glasaal in de Schutkom}

Het onderzoek in de schutkom had specifiek betrekking op de visvriendelijke maatregelen die daar in 2016 in werking zouden treden, de vishevel passage en extra loze schuttingen van de schutsluis. Ook voor de schutkom werden drie hypotheses opgesteld:

1) Door de maatregelen zal er minder ophoping van glasaal plaatsvinden rond wordt het lozingspunt van de RWZI (nabij locatie schutkom 1).

In 2016 bevinden de hoogste aantallen glasaal zich nog steeds op bemonsteringspositie 1 dus in de directe nabijheid van het RWZI-lozingspunt. Wel is het aandeel dat zich ophoudt op de posities nabij de vishevelpassage en de schutluis in 2016 lager dan in 2015. Dit zou goed het gevolg kunnen zijn van de glasaalvriendelijke maatregelen die in 2016 actief waren. Op basis van de schatting dat zich tijdens de bemonsteringen van 2016 minimaal 200.000 glasalen bevonden in de schutkom en het gegeven dat in diezelfde periode 731.775 glasalen in de vishevelpassage werden aangetroffen (FishFlow Innovations, 2016) ligt een geringe invloed van deze maatregel in de lijn der verwachtingen.

2) Door de maatregel is de verblijftijd van (gekleurde) glasalen in het onderzoeksgebied korter in 2016 dan in 2015

De resultaten van de merk-terugvangexperimenten suggereren dat de glasalen slechts minder dan 5 dagen in de schutkom verbleven. De gekleurde alen die later in de hevelpassage worden gevangen zijn zeer waarschijnlijk alen uit het opvolgende experiment in de spuikom. Er zijn geen aanwijzingen gevonden dat deze verblijftijd veranderde toen in 2016 de glasaal-maatregelen actief werden.

3) Door glasaalvriendelijk spuibeheer (glasaalmaatregel) van de Stevinsluis zal er minder glasaal vanuit de spuikom naar de schutkom zwemmen.

In 2016 zijn gekleurde glasalen die waren uitgezet in de spuikom in de vishevelpassage aangetroffen. Dit betekent dat de glasaal van de spuikom naar de schutkom zwemt. Er is voor 2016 echter geen zekerheid over de spui en visintrekstanden zodat alleen kan worden vastgesteld dat er glasalen van de spuikom naar de schutkom trekken, maar niet of dit door het spuibeheer beïnvloed wordt. In 2017, toen wel zekerheid was over de spuistanden was de vishevelpassage door een defect niet in werking tijdens de merk en terugvangexperimenten en is er geen informatie over de mogelijke effecten van de spui/visintrekstand op het zwemgedrag van de glasaal. 


\subsection{Invloed van de maatregelen op de glasaal index}

De onderzoeksresultaten bevatten teveel onzekerheden om duidelijke uitspraak te kunnen doen in welke mate de glasaalindex zal worden beïnvloed door het instellen van de glasaal-maatregelen. $\mathrm{Er}$ zijn aanwijzingen gevonden dat er subtiele veranderingen optreden in de verdeling van de glasalen over het onderzoeksgebied doordat glasalen zich minder lijken op te hopen op de locaties vlak voor de sluis waar ten bate van de indexmonitoring glasaal gevangen wordt. Waardoor de glasaalindex op een iets andere wijze in verband zal komen te staan met het aantal glasalen dat zich in de spuikom bevindt.

Belangrijker echter voor de interpretatie van de glasaalindex is echter de verblijftijd van de glasalen in het gebied. Immers, als alle glasalen onbelemmerd kunnen doortrekken naar het IJ sselmeer zullen bij de index-bemonsteringen lagere aantallen worden gevangen terwijl het aanbod hoog kan zijn. Door verschillende oorzaken is het niet gelukt om inzicht te krijgen in eventuele verschillen in verblijftijden. Het gegeven dat er slechts een subtiele verandering van de verdeling van de glasalen in het gebied lijkt te ontstaan wanneer de glasaalmaatregel wordt toegepast suggereert echter ook geen enorme verschillen in de verblijftijden. De invloed op de glasaalindex zal hiermee waarschijnlijk beperkt zijn. De op dit moment lage glasaalindex veroorzaakt een grote variatie op de index-vangsten. Hierdoor is het moeilijk om subtiele veranderingen van een ingreep aan te tonen, en niet mogelijk een correctiefactor te formuleren.

Wij schatten dat zich in 2016 en 2017 gedurende langere tijd een minimaal 1 miljoen - waarschijnlijk niet steeds dezelfde- glasalen in de spuikom bevonden. In 1996, toen de glasaalindex ook relatief laag was, schatte Dekker et al het bestand in hetzelfde gebied nog op 54 miljoen exemplaren. Bij die- ten opzichte van nu- hoge glasaal dichtheden wees Dekker et al op de onbetrouwbaarheid van de glasaalindex vangsten vanwege de grote variatie. De huidige indexvangsten zijn nog lager waardoor het zeer onwaarschijnlijk is dat een trendbreuk als gevolg van de subtiele veranderingen van de glasaalmaatregel zichtbaar zal worden in dit onderzoek. Met dit in het achterhoofd moeten we ons realiseren dat wanneer de glasaalindex stijgt, en de vangsten dus betrouwbaarder worden- dat deze gegevens niet 1 op 1 te vergelijken zijn met de situatie van voor de maatregelen. Om hier inzicht in te krijgen stellen wij in aanvulling op de index metingen, onderzoek voor waarbij de ontwikkeling van het aanbod van glasaal gevolgd wordt door periodiek, bijvoorbeeld eens per 5 jaar, het aanbod in de spuikom te schatten op basis van kruisnetmonitoring. Daarnaast kan er met de huidige glasaal index dataset ook meer analyses worden uitgevoerd in relatie tot spui en visintrekgegevens (klepstanden en debiet gegevens die in dit onderzoek niet tijdig beschikbaar kwamen). Dit rapport toont aan dat het noodzakelijk is een nauwkeurig logboek bij te houden alvorens er gedegen analyses gedaan kunnen worden. 


\section{Dankwoord}

Wij danken de gebroeders Van Malsen (WON1) en Bram van Wijk (Visserij Service Nederland) voor de ondersteuning in de glasaalvangsten in dit onderzoek.

We danken Bauke de Witte, en Carolien Breukers van Rijkswaterstaat Dienst Midden- Nederland voor alle hulp en ondersteuning in het ontsluiten van data over de spuisluisinstellingen. Jan van der Veen (RWS Watermanagement Noord-Oost) zeer bedankt voor het faciliteren in de gewenste visintrek instellingen tijdens het onderzoek in 2017.

\section{$9 \quad$ Kwaliteit}

Wageningen Marine Research beschikt over een ISO 9001:2008 gecertificeerd kwaliteitsmanagementsysteem (certificaatnummer: 187378-2015-AQ-NLD-RvA). Dit certificaat is geldig tot 15 september 2018. De organisatie is gecertificeerd sinds 27 februari 2001. De certificering is uitgevoerd door DNV Certification B.V. 


\section{Referenties}

De Vaate, A. B., A. W. Breukelaar, T. Vriese, G. De Laak, and C. Dijkers. (2003) Sea trout migration in the Rhine delta. Journal of Fish Biology 63:892-908.

ICES. (2017) Report of the joint EIFAAC/ICES/GFCM working group on eels (WGEEL).

Dekker W. (2004) Slipping through our hands: Populations dynamics of the European eel. Proefschrift Universiteit van Amsterdam.

Dekker W. en van Willigen J.A. (1997) Hoeveel glasaal trekt het IJ sselmeer in? Verslag van een glasaal-merkproef in Den Oever in 1997. RIVO-DLO rapport , 25 pp.

Dekker W. en van Willigen J.A. (2000) De glasaal heeft het tij niet meer mee! RIVO Rapport C055/00, $34 \mathrm{pp}$.

FishFlow Innovations (2016) Voorjaarsbemonstering vispassage Den Oever. Rapport FFI-1602.13

Griffioen, A. B., H. V. Winter, O. A. v. Keeken, C. Chen, E. v. Os-Koomen, S. Schoenlau, and T. Zawadowski. 2014. Verspreidingsdynamiek, gedrag en voorkomen van diadrome vis bij Kornwerderzand t.b.v. de VismigratieRivier. IMARES, IJ muiden.

Schmidt, M. (1922) The breeding places of the eel. . Philosophical Transactions of the Royal Society BBiological Sciences 211:179-208.

Sluis, M. T. v. d., N. S. H. Tien, A. B. Griffioen, O. A. v. Keeken, E. v. Os-Koomen, K. E. v. d. Wolfshaar, J. A. M. Wiegerinck, and M. Lohman. (2016) Toestand vis en visserij in de zoete Rijkswateren 2015. Wageningen Marine Research, IJ muiden.

Tesch, F. W. (2003) The eel. Blackwell Publishing.

Winter, H. V., A. B. Griffioen, and O. A. v. Keeken. (2014) De Vismigratierivier: Bronnenonderzoek naar gedrag van vis rond zoet - zout overgangen. IMARES, IJ muiden.

Wolfshaar, K. E. v. d., N. S. H. Tien, A. B. Griffioen, H. V. Winter, and M. d. Graaf. (2015) Evaluation of the Dutch Eel Management Plan 2015: status of the eel population in the periods 2005 - 2007, 2008 - 2010 and 2011 - 2013. I MARES Wageningen UR, IJ muiden. 


\section{Verantwoording}

Report C109/17

Project number: 4318100121, 4315100009, 4315100022, 4315100047, 4315100058

The scientific quality of this report has been peer reviewed by a colleague scientist and a member of the Management Team of Wageningen Marine Research

Approved: $\quad$ A.B. Griffioen

Onderzoeker

Signature:

Date:

22 december 2017

Approved:

Dr.ir T.P.Bult

Director

Signature:

Date:

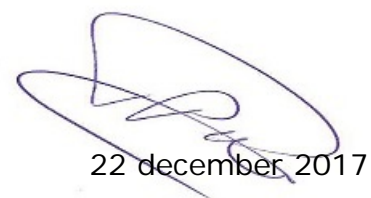




\section{Annex 1 protocol kleuren glasaal}

\section{PROCEDURE 'GLASAAL KLEUREN'}

Benodigd materiaal:

- Kruisnet om glasaal verzamelen

- Minstens $3 * 50-$ L speciekuipen (1 kuip per $2.5 \mathrm{~kg}$ te kleuren glasaal)

- Luchtpompjes (twee per kuip)

- Fijnmazig schepnet

- Eenvoudige weegschaal (1 gram nauwkeurig)

- Kleurstof (Bismarck Brown) in voorafgewogen porties van $2.5 \mathrm{~g}$ (voor $50 \mathrm{~L}$ water)

Procedure

- Weeg de te kleuren partij glasaal, noteer dit gewicht

- Vul speciekuipen met 50 liter lokaal water. Vul het aantal dat nodig om alle glasalen te verdelen in gelijke porties van maximaal $2.5 \mathrm{~kg}$ per kuip.

- Weeg zo nauwkeurig mogelijk 100 gram glasalen, in totaal 5 submonsters uit de verschillende kuipen. (gewicht/100 glasaal noteren op formulier)

- Voeg per kuip een portie $(2.5 \mathrm{~g})$ kleurstof toe zodat er een concentratie van ca. $0.05 \mathrm{~g} / \mathrm{L}$ ontstaat)

- Plaats 2 buisstenen, elk met een eigen luchtpompje, in de kuip

- Voeg maximaal $2.5 \mathrm{~kg}$ glasalen per kuip toe

- Laat de kleur gedurende 2-3 uur intrekken, controleer regelmatig de beluchting

- Verzamel na 2 uur de gekleurde glasaal en zet deze uit op de gewenste locatie.

- Noteer alle gegevens op het formulier 'glasaal kleuren' 
FORMULIER 'GLASAAL KLEUREN’

Datum:

Locatie: SCHUT-kom

I nitialen uitvoerder:

\section{Kleuren}

Kuipnr. Gewicht (g) Tijdstip in Tijdstip uit Opmerkingen

1

2

3

4

Tellen/ wegen glasaal (per 100 glasaal)

Gewicht sub monster Aantal glasalen Kuipnr.* Opmerkingen

* Kuipnummer(s) waarin de partij waaruit het getelde submonster genomen, gekleurd is 
Wageningen Marine Research

T +31 (0)317 480900

E: marine-research@wur.nl

www.wur.eu/marine-research

Visitors' address

- Ankerpark 27, 1781 AG Den Helder

- Korringaweg 7, 4401 NT Yerseke

- Haringkade 1, 1976 CP IJ muiden
Wageningen Marine Research is the Netherlands research institute established to provide the scientific support that is essential for developing policies and innovation in respect of the marine environment, fishery activities, aquaculture and the maritime sector.

\section{Wageningen University \& Research:}

is specialised in the domain of healthy food and living environment.

\section{The Wageningen Marine Research vision}

'To explore the potential of marine nature to improve the quality of life'

\section{The Wageningen Marine Research mission}

- To conduct research with the aim of acquiring knowledge and offering advice on the sustainable management and use of marine and coastal areas.

- Wageningen Marine Research is an independent, leading scientific research institute

Wageningen Marine Research is part of the international knowledge organisation Wageningen UR (University \& Research centre). Within Wageningen UR, nine specialised research institutes of the Stichting Wageningen Research Foundation have joined forces with Wageningen University to help answer the most important questions in the domain of healthy food and living environment. 